\title{
NOTE
}

\section{THE EVOLUTION OF USEFUL LIFE STATUTES IN THE PRODUCTS LIABILITY REFORM EFFORT}

\section{INTRODUCTION}

A great deal of scholarly attention ${ }^{1}$ and a wide range of legislative reform efforts ${ }^{2}$ have been devoted to solving the problems associated with injuries caused by aging products. As products age, it becomes more difficult to determine whether natural deterioration or defective inanufacture caused an accident to occur. As a result, the tension between ensuring that manufacturers are causally connected with the injury and mjured plaintiffs are compensated for life altering injuries becomes particularly acute when older products are involved. ${ }^{3}$ Perhaps this explains why many of the reforms generated in the wake of the "insurance crisis"4 were directed toward limiting the liability horizon of manfacturers to prevent claims implicating the condition of older products.

Speculation about the existence of an "insurance crisis" during the 1970s and 80s engendered considerable debate over the state of products liability law in this conntry. Although the doctrine of strict liability simplified the products hability action enormously by allowing recovery solely on a showing of product defect, ${ }^{5}$ it also placed substantial liability burdens on manufacturers. According to critics, the favorable presumptions created by strict liability played a large role in the increasing number and success rate of products liability actions. Insurance compa-

1. For example, in 1983 New York University School of Law devoted an entire issue to the problems associated with aging products. See The Passage of Time: The Implications for Product Liability, 58 N.Y.U. L. REv. 733 (1983).

2. See infra notes 77-78 (discussing various legislative reform efforts).

3. See McGovern, The Variety, Policy and Constitutionality of Product Liability Statutes of Repose, 30 AM. U.L. REV. 579, 581 (1981) (older products implicate competing concerns of legislature to set bounds of compensable harm and courts to protect legitimate rights of action).

4. See, e.g., Daily v. New Britain Mach. Co., 200 Conn. 562, 578-79, 512 A.2d 893, 902 (1986) (citing product liability "crisis" as one reason for confining remedy for injured employees to workers compensation provisions).

5. Restatement (SECOND) OF ToRTS $§ 402 A$ (1965). 
mes insisted that the drastic rise in both claims and awards necessitated increases in premiums that inany small businesses found unaffordable. ${ }^{6}$

Manufacturers and insurers argued that overzealous efforts to protect plaintiffs had pushed the tort system to an extreme position and ineasures needed to be taken to restore the system to a state of equilibrium. Proponents of tort reform concentrated their attacks on suits involving older products and the seemingly indefinite period of liability to which manufacturers were exposed. 7 Various attempts were made to limit the period in which manfacturers could be held liable for injuries caused by their products. The cries for reform, however, were not solely a recent phenomenon. In fact as early as 1957 , manufacturers were bemoaning the extent of their liability for durable goods and insisting that "public policy requires some defimite limitation of liability."8

In response to claims by the insurance lobby that extended liability generated claims far beyond their capacity to compensate, many states passed legislation designed to abbreviate the period in which manufacturers could be held hable. ${ }^{9}$ Rather than craft a thoughtful solution to the difficult questions surrounding liability for older products, many legislatures unartfully "solved" the problem by passing "statutes of repose."10 These statutes differ from statutes of hinitation in that they begin to run upon manufacture rather than injury, and they run for a greater length of time. By beginning the limitations or repose period at manufacture, however, statutes of repose also have the uufortunate effect of barring actions even before a potential plaintiff has been injured. ${ }^{11}$

6. See United States Dep't of Commerce, Interagency TASK Force on Product LIABILITY: FINAL REPORT xxxviii (1977) [hereinafter FINAL REPORT]. The report, however, contends that claims of insurance unavailability during this time were largely exaggerated. Id. at xxxv.

7. See, e.g., id. at VII-20, VII-28 (finding "merit in the suggestion that a statute should set forth a period of time during which a manufacturer's duty under tort law would terminate").

8. See International Derrick \& Equip. Co. v. Croix, 241 F.2d 216, 221 (5th Cir.), cert. denied, 354 U.S. 910 (1957) (holding that passage of time does not prevent liability per se for negligent design and manufacture when jury finds product was defective at time of sale).

9. See infra notes $60-75$ and accompanying text.

10. See infra notes 80-109 and accompanying text.

11. See, e.g., Wilson v. Dake Corp., 497 F. Supp. 1339, 1340 (E.D. Tenn. 1980) (plaintiffs claim against product manufactured 16 years earlier barred by Tennessee's 10-year statute of repose); Arsenault v. Pa-Ted Spring Co., 203 Conn. 156, 158-59, 523 A.2d 1283, 1284 (1987) (claim based on injury caused by 14-year-old industrial oven barred by 10-year statute of repose). One commentator has termed this effect "death before conception." Kratky, Statutes of Repose in Products Liability: Death Before Conception?, 37 Sw. L.J. 665 (conciuding "statutes of repose for products actions are contrary to the philosophy behind strict products liability because such statutes deprive the injured consumer of his right of action"). 
Whereas the majority of states undertaking reform opted for this rather draconian approach, ${ }^{12}$ a few states have adopted "useful life statutes," 13 a less extreme measure imitially implemented by the Model Uniform Product Liability Act (MUPLA). ${ }^{14}$ Useful life statutes function much like statutes of repose by eliminating liability for injuries caused after completion of a particular period of repose. ${ }^{15}$ The repose period for useful life statutes, however, is determined by the trier of fact on a caseby-case basis rather than by statute. ${ }^{16}$ If the trier of fact determines that a product's useful life has expired, then the plaintiff's action is barred. ${ }^{17}$

Although statutes of repose have received a great deal of attention from the academic community, ${ }^{18}$ the concept of useful life has received coinparatively hittle attention froin commentators. ${ }^{19}$ To date, relatively few cases have been decided under the useful life provisions presently im effect, and as a result the doctrime lias received ouly limited analysis.

In an effort to place the concept of useful life imto historical perspective, this Note begins by discussimg the traditional common law strict liability action, devoting particular attention to the common law treat-

12. See Dworkin, Federal Reform of Product Liability Law, 57 Tul. L. Rev. 602, 604 \& nn.10 \& 12 (1983) (stating two-thirds of states have adopted some measure of tort reform and listing 21 states adopting a statute of repose).

13. See ARK. Stat. ANN. § 16-116-105(c) (1987) (using expiration of product's useful life as factor in coinparative negligence determination); CONN. GEN. STAT. § 52-577a (c) (1987) (providing useful life limitations period for plaintiffs not covered by workers compensation provisions); IDAHO CODE § 6-1403(2) (Supp. 1987) (establishing rebuttable presunption that useful life expires after 10 years); KAN. StaT. ANN. $§ 60-3303$ (1983) (same); MiNN. STAT. $\$ 604.03$ (1988) (expiration of useful life is defense to products hability action); TENN. CODE ANN. § 29-28-103(a) (1980) (action must be brought within 10 years from purchase or 1 year after expiration of useful life, whichever is shorter); WASH. REv. CODE ANN. $§ 7.72 .060$ (Supp. 1987) (useful life rebuttably presuined to expire 12 years after delivery).

14. President Ford responded to the cries for reform by naming a task force to study the emerging "crisis" in products liability. See McGovern, supra note 3, at $579 \mathrm{n} .1$ (1981). The MUPLA was the end product of the Interagency Task Force on Product Liability's efforts. See MODEL UN1F. Product LaABILITY ACT, 44 Fed. Reg. 62,714 (1979) [hereinafter MUPLA].

15. "Period of repose" or "repose period" describes the tine witlim which a plaintiff can bring an action. Both statutes of limitation and useful life statutes are forms of repose. See infra notes 7980,85 .

16. See Morse v. City of Toppenish, 46 Wash. App. 60, 64, 729 P.2d 638, 641 (1986) (court terms useful ife statute a statute of repose with a judicially determined limitations period set by product's anticipated life); see also infra notes $169-73$ and accompanying text.

17. See infra note 170 and accompanying text.

18. A generalized search of "statutes of repose" on LEXIS will turn up alinost 60 articles.

19. See, e.g., McGovern, supra note 3, at 586 (briefly addressing useful life statutes and describing thent as a ininor variation on statutes of repose); Schwartz, New Products, Old Products, Evolving Law, Retroactive Law, 58 N.Y.U.L. Rev. 796, 848-51 (1983); Special Project, An Analysis of the Legal, Social, and Political Issues Raised by Asbestos Litigation, 36 VAND. L. REv. 573, 654 n.482 (1983). One Note does concentrate on Washington State's useful life provision, but it does not address the practical problems associated with implementing the statute or the failure to warn dilemma. Note, Washington's Useful Safe Life: Snipping Off the Long Tail of Product Liability?, 57 WASH. L. REV. 503 (1982). 
ment of older products. Next, the Note discusses the precursor to useful life statutes, statutes of repose, analyzing the arguments both for and against such statutes as instruments of tort reform. It then exainines the relation of statutes of repose to useful life statutes, and concludes that the concept of useful life represents an equitable, if somewhat ill-defined, solution to the dilemma created by suits involving older products. This Note proposes a method for calculating useful life that increases the ability of imsurers and manufacturers to calculate their future exposure to liability and reduces the uncertainty that often fuels increased premiums, while retaining the flexibility lacking in statutes of repose. It argues that useful life must be determined based on the average expected life of a manufacturer's product, rather than the useful life of a specific product, if the statute is to represent a significant advance over the common law treatment of older products. This Note suggests that states that have attempted to teinper the rigidity of statutes of repose by adopting a product-specific approach for the calculation of useful life have in essence gone full circle, vitiating many of the advantages of the statute by simply codifying existing common law principles.

Finally, this Note maintains that to be effective, useful life statutes must be interpreted as applying to all actions against manufacturers, including failure to warn claims. Courts in repose jurisdictions have disagreed over whether provisions that begin at manufacture should apply to a breach of the duty to warn. ${ }^{20}$ Under traditional statutes of limitation, courts generally have accepted what is termed the "continuing course of conduct" exception and have held that a breach of the duty to warn is ongoing and continuing, thereby preventing the limitations period from commencing until the time of injury. ${ }^{21}$ As a result, plaintiffs whose actions could be foreclosed by a useful life statute or statute of repose may contend that a failure to warn constitutes a continuing course of conduct, which is not susceptible to a limitations period beginning on manufacture. ${ }^{22}$ This Note concludes that the continuing course of conduct exception is fundamentally inconsistent with the concepts underly. ing useful life provisions, and therefore this exception should not be used to evade the limitations period created by useful life statutes.

20. Compare Drakatos v. R.B. Denison, Inc., 493 F. Supp. 942, 945 n.3 (D. Conn. 1980) (failure to warn is continuing duty that does not trigger statute of limitation until injury) with Wilson v. Dake Corp., 497 F. Supp. 1339, 1339.40 (E.D. Tenn. 1980) (court rejects plaintiff's attempt to avoid statute of repose by claiming failure to warn is a continuing course of conduct) and Dague v. Piper Aircraft Corp., 275 Ind. 520, 527, 418 N.E.2d 207, 211-12 (1981) (same).

21. See infra note 219 and accompanying text.

22. See infra notes $230-50$ and accompanying text. 


\section{BACKGROUND}

\section{A. The Rationale Behind Striçt Products Liability}

Prior to the adoption of strict products liability, negligence and breach of warranty actions provided the inain avenues of recovery for product-related injuries. ${ }^{23}$ However, numerous impediments severely curtailed a plaintiff's ability to seek redress under either of these theories. For years, inanufacturers successfully used the privity doctrine to prevent all but the original purchaser from recovering under a breach of warranty theory. ${ }^{24}$ Manufacturers also could defeat an action by deinonstrating that the plaintiff liad not relied on the manufacturer's representations concerning product quality. ${ }^{25}$ In negligence actions, moreover, plaintiffs encountered difficulty in proving that the defendant was actually responsible for the defect or that appropriate safety measures would have uncovered the problem prior to sale. ${ }^{26}$

The perceived inequity of allowing manufacturers to introduce defective products into the marketplace with such limited ineans of legal recourse available to individuals injured by their products led to a gradual relaxation of the traditional requirements for recovery. ${ }^{27}$ To ameliorate the liarsh effects on plaintiffs, courts began to stretcli warranty and negligence principles far beyond their traditional bounds. Actions in negligence, for example, were aided greatly by the more frequent applica-

23. See Greenman v. Yuba Power Prods., 59 Cal. 2d 57, 62, 377 P.2d 897, 900 n.2, 27 Cal. Rptr. 697, 700 n.2 (1963) (quoting statutory definition of express warranty); Henningseu v. Bloomfield Motors, 32 N.J. 358, 370, 161 A.2d 69, 76 (1960) (discussing general requirements for breach of warranty); see also Traynor, The Ways and Meanings of Defective Products and Strict Liability, 32 TENN. L. REv. 363, 364-65 (1965) (suggesting that breach of warranty principles are less than ideally suited to products liability actions); Prosser, The Assault upon the Citadel (Strict Liability to the Consumer), 69 Y ALE L.J. 1099, 1114 (1960) (discussing the elements for an action in negligence).

24. See Prosser, The Fall of the Citadel, 50 MinN. L. Rev. 791, 801 (1966) (discussing privity road block to recovery under breach of warranty); Prosser, supra note 23, at 1117-18 (same). The court in Henningsen, however, refused to recognize the defendant's privity defense. Henningsen, 32 N.J. at $412-13,161$ A.2d at 99-100.

25. See Yuba Power Prods., 59 Cal. 2d at 64, 377 P.2d at 901, 27 Cal. Rptr. at 701 (plaintiff must prove violation of an express warranty by demonstrating he "read and relied on the representations ... in the manufacturer's brochure"); Prosser, supra note 24, at 801 (discussing opportunity for defendant to show plaintiff did not rely on representation); Prosser, supra note 23, at 1129 (same).

26. Cf. Henningsen, 32 N.J. at 372, 161 A.2d at 77 (importance of strict liability is that plaintiff need not show defendant was negligent). But see Prosser, supra note 23, at 1114 (discounting diffculty of recovering in negligence and claiming there is "not one case in a hundred where strict liability would result in liability where negligence does not").

27. See Henningsen, 32 N.J. at 371,161 A.2d at 76-77 (courts interpreting traditional actions more liberally to take account of changing business practices and provide greater protection for consuners); RESTATEMENT (SECOND) OF TORTS $\S 402 A$ comment $c$ (1965) (indicating policy choice to force those who benefit from the sale of a product to bear the cost of injuries resulting from its use); Traynor, supra note 23, at 365 (courts stretched reasoning to find promise by manufacturer to support breach of warranty claim). 
tion of the doctrine of res ipsa loquitur, which allowed the trier of fact to presume neghigence from the mere existence of a defect. ${ }^{28}$ In claims for breach of warranty, courts attempted to create a tort-like action out of a contract principle by enforcing implied warranties and warranties that "ran with the goods." 29 Both of these concepts allowed subsequent users, who might otherwise have been barred by the privity doctrine, to assert claims against the manufacturer. ${ }^{30}$ The old theories of liability, however, simply were not designed to provide relief under these circuinstances, and their forced application to product-related injuries led to rather contrived and attenuated reasoning. ${ }^{31}$ Courts eventually realized that in essence they already were applying principles of strict liability, and they could avoid the judicial acrobatics necessary under negligence and breach of warranty theories by adopting a nore straightforward approach to producer hability. ${ }^{32}$

The concurring opinion of Justice Traynor in the 1944 case of Escola v. Coca Cola Bottling Co. laid the groundwork for the introduction of what Traynor termed "absolute hability." 33 However, it was not until the 1960 decision in Henningsen v. Bloomfield Motors Co. ${ }^{34}$ and the 1963 ruling in Greenman v. Yuba Power Co., ${ }^{35}$ that courts exphicitly adopted the doctrine of strict hability in tort. Shortly thereafter, the Restatement

28. See Prosser, supra note 24, at 800 ; Prosser, supra note 23, at 1114; Schwartz, supra note 19, at 829 (comparing presumption of strict liability to negligence doctrine of res ipsa loquitur); Traynor, supra note 23, at 364 (invocation of res ipsa loquitur permits inference of negligence froin presence of defect).

29. See Henningsen, 32 N.J. at 408, 161 A.2d at 97 (discussing implied warranty); Prosser, supra note 23 , at $1126-34$.

30. See, e.g., Henningsen, 32 N.J. at $412-13,161$ A.2d at $99-100$ (court rejects traditional privity defense).

31. See Traynor, supra note 23 , at 365 (describing application of warranty principles to tlis area as "tortured").

32. See Greeno v. Clark Equip. Co., 237 F. Supp. 427, 429, 432 (N.D. Ind. 1965) (court adopts strict liability; states strict liability is nothing more than "innplied warranty when stripped of the contract doctrines" attached to it and suggests it is time to give doctrine a fresh name to abandon "old entanglements"); Greenman v. Yuba Power Prods., 59 Cal. 2d 57, 63, 377 P.2d 897, 901, 27 Cal. Rptr. 697, 701 (1963) (citing earlier cases ostensibly based on breacli of warranty as support for the imposition of strict liability in tort); Escola v. Coca Cola Bottling Co., 24 Cal. 2d 453, 461, 150 P.2d 436, 440 (1944) (Traynor, J., concurring) (negligence theory sliould be abandoned in favor of absolute liability); Peck, Comments on Judicial Creativity, 69 IowA L. REv. 1, 14 (1983) (courts abandoned "camouflaging devices" and openly imposed strict liability); Prosser, supra note 23, at 1119,1134 (doctrine of res ipsa loquitur is applied to impose liability on defendants who lave not been negligent at all; "strict liability inerely formulates, as a general rule, wliat goes on all the time in fact"); Traynor, supra note 23, at 365 (courts rejecting fiction of warranty theory and imposing strict liability outright).

33. 24 Cal. $2 d$ at $461-68,150$ P.2d at $440-44$ (Traynor, J., concurring).

34. 32 N.J. 358,161 A.2d 69 (1960).

35. 59 Cal. 2d 57, 377 P.2d 897, 27 Cal. Rptr. 697 (1963). 
of Torts accepted the doctrine, ${ }^{36}$ and it quickly gained widespread acceptance in the common law. ${ }^{37}$

Courts and commentators justified the new theory of liability on a number of grounds. ${ }^{38}$ By placing goods on the market, they maintained, manufacturers implicitly warrant their products to be safe and suitable for their intended use. ${ }^{39}$ In addition, manufacturers were perceived as the least cost risk avoider since tliey are in the best position to detect and remedy various liazards. Moreover, the imposition of liability furthers the incentive for manufacturers to take appropriate safety precautions. ${ }^{40}$ Manufacturers can also spread the cost of compensation and the risk of injury across all consumers by incorporating the additional cost into the price of the product, whereas an uncompensated injury would deal a devastating blow to an mdividual plaintiff. ${ }^{41}$

The doctrine of strict liability, at its inception, produced a simple, straightforward cause of action, free from the legal fictions associated with the cumbersome negligence and breacl of warranty actions that

36. Restatement (SECOND) OF TORTS $§ 402 A$ (1965).

37. The products liability field has often been influenced by the effect of one persuasive opinion. Justice Cardozo's "dangerous instrumentality" test in McPherson v. Buick Motor Co., 217 N.Y. 382, 389, 111 N.E. 1050, 1053 (1910), spread quickly, see Prosser, supra note 23, at 1100, as did the opimion in Henningsen, see Prosser, supra note 24, at 793-97, and the California court's reasoning in Greenman. See Prosser, supra note 24, at 803-04.

38. See, e.g., Prosser, supra note 23, at 1134 (suggesting that numerous public policy rationales dictated the adoption of strict hability). But see Plant, Strict Liability of Manufacturers for Injuries Caused by Defect in Products-An Opposing View, 24 TenN. L. Rev. 938, 944 (1957) (recommendation of strict liability for manufacturer is a limited one, limited to manufacturers of finished products, and to personal injury, as opposed to property damage claims).

39. See Santor v. A \& M Karagheusian, Inc., 44 N.J. 52, 64-65, 67, 207 A.2d 305, 311, 313 (1965) (manufacturers implicitly represent that article is safe for general purposes when placed in stream of trade); Greenman, $59 \mathrm{Cal} .2 \mathrm{~d}$ at 64, 377 P.2d at 901, $27 \mathrm{Cal}$. Rptr. at 701 (presence of product on market implicitly represents it is safe for intended purpose); Prosser, supra note 23, at 1123 (same).

40. See Escola v. Coca Cola Bottling Co., 24 Cal. 2d 453, 462, 150 P.2d 436, 440 (1944) (Traynor, J., concurring) (" $[\mathrm{I}] \mathrm{t}$ is evident that manufacturers can anticipate some hazards and guard against the recurrence of others, as the public cannot.").

41. See Greenman, $59 \mathrm{Cal} .2 \mathrm{~d}$ at $63,377 \mathrm{P} .2 \mathrm{~d}$ at 901, $27 \mathrm{Cal}$. Rptr. at 701 (purpose of strict liability is to insure costs of injuries caused by defeetive products are borne by manufacturers rather than innocent plaintiffs); Escola, $24 \mathrm{Cal} .2 \mathrm{~d}$ at $462,150 \mathrm{P.2d}$ at 441 (manufacturers can distribute cost of compensating injured among all users by including amounts paid in cost of doing business); Santor, 44 N.J. at 65, 207 A.2d at 312 (purpose of strict liability to insure that costs of compensating injured are borne by makers of defective product); McGovern, supra note 3, at 590 (explaining that regardless of fault, manufacturers in best position to take measures to reduce risk of defect and to pass costs on to consumers generally); Prosser, supra note 23, at 1120 (manufacturers are in a better position to absorb losses and, through their prices, to pass such losses on to the community at large); see also RestateMENT (SECOND) OF TORTS $\S 402 A$ comment $c$ (1965) (favoring policy to force those who benefit from sale of a product to bear the cost of injuries that result from its use); Schwartz, supra note 19, at 825 (discussing product liability rationale of risk spreading and resource allocation in the context of retroactive application of liability rules). 
preceded it. 42 In a strict liability action, the plaintiff only needs to prove that the product was defective and the defect was the proximate cause of his injury. ${ }^{43}$ The doctrine allows the trier of fact to infer negligent conduct on the part of the manufacturer upon a showing that the product was originally defective. ${ }^{44}$ Courts have defined the terin "defective" as a condition that does not ineet an ordimary consumer's expectations regarding safety. ${ }^{45}$ Under strict liability principles, the plaintiff does not have to demonstrate directly that the product was defective. In fact, such a requirement would place a rather substantial burden on plaintiffs considering that the product involved in the accident often will be destroyed, making any expert analysis impossible. Instead plaintiffs may use circumstantial evidence to prove that a product contained a defect, ${ }^{46}$ and the trier of fact may assume tliat a product defect caused the accident if one would not expect a problein of this kind to arise at this stage in the product's life.47 Although liability will be imposed even if a defendant can demonstrate that it exercised all possible care, ${ }^{48}$ the defendant can attempt to slow thiat the accident actually resulted from natural deterioration, ${ }^{49}$ abnormal use, ${ }^{50}$ lack of proper maintenance, ${ }^{51}$ or modifi-

42. See McGovern, supra note 3, at 590 (strict liability attempts to simplify recovery by injured party); Prosser, supra note 23, at 1123-24 (strict liability is judicially honest approach that produces a simplified action).

43. See Greenman, 59 Cal. 2d at 62, 377 P.2d at 900, 27 Cal. Rptr. at 700 (manufacturer is strictly liable in tort for defective products); Farmer v. International Harvester Co., 97 Idaho 742, 746-47, 553 P.2d 1306, 1310-11 (1976) (plaintiff must show he was injured by defendant's product, imjury was result of defective or unsafe product, and defect existed at time left defendant's control).

44. See Montez v. Ford Motor Co., 101 Cal. App. 3d 315, 319, 161 Cal. Rptr. 578, 580 (1980) (in strict hability, defect is shortcut to showing of negligence). The rationale for the inference of negligence appears to be the behief that it is the rare case in which the defendant will not have been negligent when the product is defectively manufactured. Schwartz, supra note 19, at 809-10 (experience shows correlation between product defect and negligence is so high that courts are justified in creating irrebuttable presumption that the manufacturer is liable for defect); $c$. Dworkin, Product Liability in the 1980's: "Repose Is Not the Destiny" of Manufacturers, 61 N.C.L. REv. 33, 42 (1982) (defendants are presumed responsible due to importance of protecting plaintiffs without a remedy).

This doctrine is derived from the earlier use of res ipsa loquitur in negligence actions. See supra note 28 and accompanying text.

45. Farmer v. International Harvester Co., 97 Idaho 742, 747, 553 P.2d 1306, 1311 (1976); see also RESTATEMENT (SECOND) OF TORTS $§ 402 \mathrm{~A}$ comment $\mathrm{g}$ (1965) (defect not contemplated by user would be unrcasonably dangerous).

46. See Farmer, 97 Idaho at 747-48, 553 P.2d at 1311-12; Henningsen v. Bloomfield Motors Inc., 32 N.J. 358, 409, 161 A.2d 69, $97-98$ (1960) (court presumes from nature of the accident that defect was original); see also supra note 28 and accompanying text (discussing inference of negligence and res ipsa loquitur doctrine).

47. See Scanlon v. General Motors, 65 N.J. 582, 593, 326 A.2d 673, 679 (1974).

48. RESTATEMENT (SECOND) OF TORTS $§ 402 A$ comment a (1965).

49. See, e.g., Kaczmarek v. Mesta Mach. Co., 463 F.2d 675, 678 (3d Cir. 1972) (no duty to producc product that will not wear out; industrial chain involved in accident badly worn).

50. See, e.g., Kaczmarek, $463 \mathrm{~F} .2 \mathrm{~d}$ at $678-79$ (manufacturer not liable for products subjected to improper use). 
cation or alteration. ${ }^{52}$ Manufacturers often claim that strict liability has made them the insurers of their products, but courts insist that the doctrine retains principles of fanlt and warranty by imposing liability only for injuries caused by product defects ratler than all injuries associated with product use. 53

\section{B. Strict Liability, Older Products, and the Insurance Crisis}

Courts liave been dealing with suits involving aging products for quite some time, ${ }^{54}$ but the analysis they have utilized has changed considerably over the years. At one time, courts in negligent inanufacture cases presumed that the extended use of a product without incident provided sufficient proof that natural deterioration was responsible for the accident and thus the product was not inanufactured negligently. ${ }^{55}$ Eventu-

51. See, e.g., Ulrich v. Kasco Abrasives Co., 532 S.W.2d 197, 201 (Ky. 1976) (manufacturer entitled "to rely on the owner of the machine to assume responsibility for keeping it im safe working order"); Auld v. Sears, Roebuck \& Co., 261 A.D. 918, 918, 25 N.Y.S.2d 491, 493 (1941), affd, 288 N.Y. 515, 41 N.E.2d 927 (1942) (duty to maintaim rests with user, and hability cannot be imposed when accident due to improper maintenance). For a statutory version of the improper maintenance defense, see N.C. GEN. STAT. § 99B-3(b) (1989) (manufacturer or seller of a product is not liable in product liability when product has been altered or modified, including "failure to observe routine care and maintenance").

52. See, e.g., Frey v. Rockford Safety Equip. Co., 546 N.Y.S.2d 54, 55 (1989) (defendant not liable if user modification substantially alters product). For statutory versions of the user modification defense, see N.C. GEN. STAT. § 99B-3(a) (1989) (no liability "where a proximate cause of the personal injury, death or damage to property was either an alteration or modification of the product by a party otler than the manufacturer or seller ... [and] after the product left the control of such manufacturer or such seller"); IND. CODE 333-1-1.5-4(b)(3) (Burns Supp. 1989) (no liability if the "modification or alteration is the proximate cause of physical harm where sucl modification or alteration is not reasonably expectable to the seller").

53. See State Stove Mfg. Co. v. Hodges, 189 So. 2d 113, 120-21 (Miss. 1966), cert. denied, 386 U.S. 912 (1967) (manufacturers uot insurers of their products because they are only liable for injuries caused by product defects, not all aceidents involving their goods); Schwartz, supra note 19, at 80910 (negligence principles built into strict liability because holding manufacturers liable for all injuries caused by products would offend notions of equity); Traynor, supra note 23, at 366-67 (clear that manufacturers are not insurers for their products since not responsible for all injuries caused by their products).

Holding a knife mauufacturer liable wheu the user cuts himself provides the classic example of making manufacturers the insurers of their products. See Traynor, supra note 23, at 367. Such absolute liability, however, is not imposed. Workers compensation statutes offer a good example of an area in which absolute liability is imposed. These statutes require only a slowing of on the job injury before a worker can recover. See, e.g., TENN. CODE ANN. § 50-6-103 (1983).

54. See, e.g., Pryor v. Lee C. Moore, Corp., 262 F.2d 673 (10th Cir. 1958) (imposing liability on 15-year-old oil rig for defeetive weld), cert. denied, 360 U.S. 902 (1959); Mondshour v. General Motors Corp., 298 F. Supp. 111 (D. Md. 1969) (court rejects plaintiff's negligent design claim against bus manufactured 17 years earlier).

55. See, e.g., Lynch v. International Harvester Co. of America, 60 F.2d 223, 224 (10th Cir. 1932) (five years safe use gives rise to inference product was not defective when manufactured); Solomon v. White Motor Co., 153 F. Supp. 917,920 (W.D. Pa. 1957) (between 200,000 and 400,000 miles safe use indicates automobile not defective). 
ally, however, courts rejected this type of reasoning, recognizing that defect and causation were questions of fact that could not be determined as a matter of law. ${ }^{56}$ The courts in these cases found that the age of the product is relevant in a determination of original defect, but is not dispositive. In Pryor v. Lee C. Moore, Corp., the court held that "[p]rolonged use of a inanufactured article is but one factor, albeit an important one, in the determination of the factual issue whether the negligent manufacture proximately caused the harm." 57 Courts adopting this reasoning no longer assumed that the mere passage of time conclusively determined that the product was free froin defects, but instead recognized that a product defect inay lay dormant for years before the proper combination of circumstances brings the problein to light. 58 Although extended use miglit provide reliable evidence concerning the degree of natural deterioration and the role wear and tear inay have played in the injury, the real focus in a product hability action centers not on how long the product lasted, but on what caused the product's failure. ${ }^{59}$

Whereas the common law originally presuined that extended use of a product without injury conclusively denonstrated that the product was not neghigently manufactured, strict liability presumes negligence froin the existence of a defect regardless of the product's age. As a result, the discovery of a defect after extended use no longer gives rise to a presumption in favor of the inanufacturer; instead strict liability principles assume the manufacturer was negligent despite the product's age. The adoption of strict liability, tlierefore, essentially resulted in a coinplete reversal of the traditional coinmon law presumption.

Courts always have recognized that manufacturers are under no duty to produce a product that does not wear out. ${ }^{60}$ As time passes, liowever, courts have greater difficulty in determining whether an accident was caused by a latent defect or by the normal wear and tear associ-

56. See Pryor, 262 F.2d at 675 (specifically rejecting contention in Lynch and progeny that passage of time can bar an action); Derrick \& Equip. Co. v. Croix, 241 F.2d 216, 221 (5th Cir. 1957) (passage of time does not per se bar action).

57. See Pryor, 262 F.2d at 674.

58. See Beadles v. Servel, 344 IIl. App. 133, 146, 100 N.E.2d 405, 412 (1951) ("In this light the period of satisfactory service before the defect caused harm does not indicate the machine was not defective as a matter of law, but merely that the defect was more insidious than sudden in its capability to cause harm.").

59. See Cryts v. Ford Motor Co., 571 S.W.2d 683, 689 (Mo. Ct. App. 1978) (time, while relevant, is not dispositive; one must inquire not into how long product lasted, but what caused defect).

60. See Barich v. Ottenstror, 170 Mont. 38, 44, 550 P.2d 395, 398 (1976) (manufacturer not required to produce or sell product that will not wear out); Jakubowski v. Minnesota Mining \& Mfg. Co., 42 N.J. 177, 185, 199 A.2d 826, 831 (1964) ("no duty on the part of the manufacturer to furnish tools which will not wear out"); see also Comment, $A$ Time-Dependent Model of Products Liability, 53 U. CHI. L. Rev. 209, 213 n.14 (1986). 
ated with aging products. ${ }^{61}$ In addition, the passage of time increases the possibility that intervening causes such as faulty repair, alteration, or poor maintenance are actually to blame. ${ }^{62}$ When an aging product is involved, juries may blur the distinction between defect and deterioration, overlook the possibility of an intervening cause, or simply give the benefit of the doubt to the plaintiff, all of which make courts' repeated assurances that manufacturers are not required to produce goods with an infinite lifetime far less comforting.

The insurance industry, manufacturers, and others who advocate various methods of tort reform insist that as products age, many justifications for imposing strict hability become less persuasive. For example, strict hability allows plaimtiffs to recover for an accident caused by a defective product even if the defendant can prove that all possible precautions had been taken. The theory rests on the assumption that manufacturers are in the best position to minimize the risk of product defects. Manufacturer efforts to implement additional safeguards, however, are far less likely to uncover the type of latent defects involved in suits against older products which may not manifest themselves until long after manufacture. Under a neghigence theory, if no measures could be taken to detect and remedy such long term difficulties, then manufacturers would have escaped hability. Under principles of strict hability, however, the presence of a defect, whether remediable or not, assures recovery. In order to alter this outcome, some commentators have suggested that courts resurrect part of the traditional analysis by subjecting older products to a neghigence standard rather than strict liability. ${ }^{63}$

Although manufacturers and insurers typically have the ability to forecast potential hability and thus can include these costs in the price of

61. See Savage v. Jacobsen Mfg. Co., 396 So. 2d 731, 732 (Fl. Ct. App. 1981) (product not defective; non-skid surface on mower simply wore off); Jakubowski, 42 N.J. at 184, 199 A.2d at 830 ("It is common knowledge that materials subject to friction will wear out."); Gomez v. E.W. Bliss Co., 27 Misc. 2d 649, 651, 211 N.Y.S.2d 246, 248 (Sup. Ct. 1961) (nine years of constant use resulted in worn parts which caused injnry, not defective manufacture).

62. See Daily v. New Britain Machine Co., 200 Co1m. 562, 583-84, 513 A.2d 893, 904-05 (1986) (older products involve increased likelihood of misuse, alteration, or negligent repair); Schwartz, supra note 19, at 845 (although the amount of available evidence decreases over time, the number of possible alternative causes increases); Note, supra note 19, at $506 \mathrm{n} .25$ (older claims create probleins for both plaintiffs and defendants by introducing the increased possibility that intervening cause is actually responsible for injury).

Many conimentators suggest that the burden of disproving the existence of intervening causes such as poor maintenance, alteration, intense use, or simple wear and tear should be placed on the plaintiff because it is difficult for the defendant to know what has happened to the product in the interin between manufacture and injury. See Schwartz, supra note 19, at 830-31 (plaintiff must disprove intervening causes). Conversely, plaintiffs have difficulty deinonstrating that nothing has ever happened during the course of the product's life to cause the malfunction.

63. See Cominent, supra note 60, at 213-16 (snggesting strict liability for newer products and negligence standard for older products). 
the product, ${ }^{64}$ the accuracy of such forecasts diminishes the longer the product is designed to last. The adoption of the discovery rule, which commences the limitations period on injury, has subjected manufacturers to an open-ended period of liability. ${ }^{65}$ The longer the product is designed to last, the harder it becomes for the insurance industry to predict accurately how many products will still be on the market in subsequent years and, correspondingly, how many suits should be expected. In addition, due to the unlimited liability horizon created by the discovery rule, insurers must attempt to predict how liability standards will evolve over the course of the next decade and beyond-hardly an enviable task in light of the rapid changes taking place in the law currently. ${ }^{66}$

The industry has consistently maintained that the uncertainty surrounding manufacturers' liability for older products has a disproportionate impact on premiums due to the subjective nature of rate-setting. ${ }^{67}$ To compensate for the uncertamty imvolved in predicting liability exposure over an extended period of time, insurers must factor in a risk premium to protect themselves from unexpected liability. ${ }^{68}$ Some commentators argne that this uncertainty concerning potential liability places older manufacturers at a competitive disadvantage because they have more products on the market than newer entrants, and consequently they are forced to pay higher premiums to cover products that remain in use. 69

The uncertainty regarding future liability purportedly helped to create the insurance crisis of the $1970 \mathrm{~s}$ and early $1980 \mathrm{~s}^{70}$ The insurance

64. See McGovern, supra note 3, at 599-600; see also supra note 41 and accompanying text.

65. See Final Report, supra note 6, at VII-20.

66. See id. at VII-22 (insurers unable to include future liability costs into sales price duc to inability to predict basis of liability in future); $c f$. Schwartz, supra note 19, at 825 (if cost of predicting new rules of liability exceeds benefit derived from avoidance, then retroactive application of liability rules will not affect current belavior).

67. See FINAL REPORT, supra note 6, at VII-20 to -21, VII-23.

68. See McGovern, supra note 3 , at 593.

69. See FINAL RePORT, supra note 6, at VII-23. This assumes that older manufacturing companies did not correctly anticipate the degree of their future liability when the goods were originally sold, and therefore, the priee charged did not accurately reflect the cost of future insurance premiums or recoveries. While this may have been true for products manufactured in the 1950s as a result of the evolving nature of liability following the advent of the strict liability doctrine, one can now presume that the cost of goods manufactured after this time reflects a reasonable approximation of liability insurance costs stretched over the course of the product's life. See generally Prosser, supra note 24 (discussing rapid changes in field of products liability during the 1960s). Each successive model, therefore, carries in its cost a percentage reflecting insurance premiums to cover antieipated liability. Commentators, however, continue to contend that older manufacturers somehow are placed at a competitive disadvantage based on their greater exposure to liability. See Note, Alabama's Products Liability Statute of Repose, 11 CumB. L. Rev. 163, 166 (1980); Special Project, supra note 19 , at 653 .

70. See McGovern, supra note 3 , at 593 (uncertainty concerning extent of liability results in increased premiums). 
industry maintamed that if the period of liability was more clearly delimeated, terminating after a reasonable period of time, then insurers would stand a better chance of predicting what the applicable rules of law would be and also could anticipate the extent of their liability witl a greater degree of certainty. As a result, the risk premiums which insurers used in the past would no longer be necessary, rates would decline and businesses would once again be able to afford product liability insurance premiums. ${ }^{71}$

In the 1970s, studies showed an alarming increase in botli lawsuits and recoveries. Product liability awards rose from approximately 143,000 in the 1960 s to nearly 377,000 in the years between 1975 and 1979.72 Moreover, the success rate and amount of damages awarded for product liability suits also increased during this period. ${ }^{73}$ Not surprisingly, insurance rates rose rapidly. ${ }^{74}$ These developments were attributed to a number of factors, including the increased ability of attorneys in this area, the increased awareness of consumers' riglits, carelessness among consumers and inanufacturers, and clianges in the tort system itself. ${ }^{75}$

In the face of sucl daunting statistics and almost universal cries for tort reform, state legislatures sprang into action. ${ }^{76}$ Although reform took many sliapes, ${ }^{77}$ the majority of states that implemented legislation elected

71. See U.S. DEP'T OF COMMERCE, INTERAGENCY oN PRODUCT LIABILITY: Final RePORT OF THE INSURANCE STUDY 4-92 (1977) [hereinafter INSURANCE STUDY] (clear period of liability would restrain underwriters' fears by strictly limiting period of exposure); see also Mathis v. Eli Lilly \& Co., 719 F.2d 134, 139 (6th Cir. 1983) (citing preamble to Tennessee statute of repose that states purpose of Act as decreasing length of hability and uncertainty in order to decrease insurance premiums); Dworkin, supro note 44, at 35 n.10 (limiting time after manufacture during which action can be brought decreases nncertainty by improving ability of insurers to accurately calculate rates). But see Stutts v. Ford Motor Co., 574 F. Snpp. 100, 105 (M.D. Tenn. 1983) (court specifically rejects decrease in insurance rates as purpose of Tennessee's statute of repose stating that "the Act in itself will not effect lower premiums").

72. See Dworkin, supra note 12 , at 602 n.1.

73. See id.; Schwartz, supra note 19, at 812-13.

74. See Ghiardi, Products Liability-Where is the Borderline Now?, 13 Forum 206, 209 (1977) (between 1970 and 1976 insurance premiums purportedly rose over 944\%).

75. See Dworkin, supra note 44, at 33 \& n.4; Ghiardi, supra note 74, at 209; Schwartz, supra note 19 , at $812-13$.

76. Even some courts joined the chorus of cries for reform. See, e.g., Kozlowski v. John E. Smith's Sons Co., 82 Wis. 2d 882, 901, 275 N.W.2d 915, 924 (1979) (after allowing recovery, court recommends legislature adopt a statute of repose to address burgeoning problem of open-ended liability).

77. Other measures intended to limit manufacturers' liability included defenses for user modification or alteration, compliance with the state of the art existing at the time of manufacture creating a statutory bar to recovery, compliance with governmental standards in existence at the time of manufacture, and limits or caps on both compensatory and punitive damages. See FINAL REPORT, supra note 6, at VII-20 to -69; INSURANCE STUDY, supra note 71, at 4-92 to -99; Dworkin, supra note 12, at 610-15; see also Dworkin, supra note 44, at $34 \mathrm{n} .8$ (listing all the states that had taken action on product liability reform as of 1982). 
to limit the period of hability by adopting a variation on traditional statutes of limitation called statutes of repose..$^{78}$ Considering that useful life statutes are a flexible variation on statutes of repose, ${ }^{79}$ many of the justifications and criticisms offered for statutes of repose also provide an important contextual and analytical framework for the examination of useful life statutes.

\section{Statutes OF REPOSE}

\section{A. Statutes of Repose Versus Statutes of Limitation}

The principal difference between a statute of repose and a statute of limitation is the point at which the statute begins to run. ${ }^{80}$ Depending on the jurisdiction, most statutes of repose begin either upon the sale or manufacture of a product. ${ }^{81}$ In contrast, statutes of limitation usually run from the time of injury. ${ }^{82}$

This difference in timing results from the adoption of the "discovery rule" which starts the limitation period at the timie the mjury is or reasonably should have been discovered. ${ }^{83}$ As a result of strict liability's

Some states use a three year statute of himitation within a longer statute of repose to prevent those injured immediately after manufacture from waiting up to ten years before bringing an action. For example, with a 12 year statute of repose, those injured during the first nine years following inanufacture have three years in which to bring a claim, whereas those injured thereafter must file their claim prior to the expiration of the repose period. See McGovern, supra note 3, at 585; Note, supra note 19, at 508. Such provisions give the benefit of an ordinary statute of linitations to inanufacturers of non-durable goods whose products are more likely to cause injury, if at all, in the first few years following manufacture.

78. See Dworkin, supra note 12, at 604 (state legislatures responded to crisis primarily in form of statutes of repose).

79. In his discussion of statutes of repose, Professor McGovern defines useful life statutes as another type of statute of repose. See McGovern, supra note 3, at 586.

80. See Kozlowski, 275 N.W.2d at 924 (court defines statute of repose as statute of limitation that runs from the date of manufacture).

81. See, e.g., ARIz. REV. STAT. ANN. § 12-551 (1982) (strict liability actions inust be cominenced within 12 years of sale); CoNN. GEN. STAT. ANN. $\$ 52-577$ a (West Supp. 1986) (statute begins 10 years after defendant parted with the product); GA. CODE ANN. $\S 51-11$ (b)(2) (1982) (statute of repose runs for 10 years from date of sale); TENN. CODE ANN. $\$ 29-28-103$ (a) (1980) (statute of repose runs from date of purchase); see also Special Project, supra note 19, at 652 n.465 (statutes of repose start on date of delivery rather than date of injury).

82. Tort actions are governed by limitations statutes that begin when the action "accrues." See RESTATEMENT (SECOND) OF TORTS $\S 899$. This ineans they can run froin any one of three points in time: (1) from the time of defendant's breach of conduct, which for defective products would be at manufacture; (2) from the time defendant's breach results in harm; or (3) from the moinent plaintiff discovers the harm. See Developments in the Law-Toxic Waste Litigation, 99 HARv. L. REV. 1458, $1604 \&$ nn.11, 13 (1986). Modern statutes of limitation typically adopt the third alternative and run froin the date of discovery. Id.; see also infra notes 83-86 and accompanying text.

83. See, e.g., ConN. STat. ANN. § 52-577a(a) (West Supp. 1986) (claims must be brought within three years of date when injury is discovered or should have been discovered in the exercise of reasonable care). 
historical connection to breach of warranty theory, courts originally applied a contract statute of limitation to products hability cases, starting the linitations period at manufacture or sale. ${ }^{84}$ Consequently, an individual injured by a defective product might find that the limitations period had expired several years prior to injury. ${ }^{85}$ Once strict hability's conversion froin contract to tort theory was coinplete, however, courts began to utilize a limitations period that began on the day the injury was or reasonably should have been discovered. ${ }^{86}$ The discovery rule, therefore, prevented the traditional interpretation froin barring a claim before injury. ${ }^{87}$

84. See Mayo v. Rouselle Corp., 375 So. 2d 449, 451 (Ala. 1979) (product liability actions brought under contract theory subject to statutes of limitation, which commence upon the defendant's breach at time of delivery); Moss v. Polyco, Inc., 522 P.2d 622, 627 (Okla. 1974) (product liability claim barred by statute of limitations for tort, not contract or breach of warranty, beginning at time of injury); see also FINAL REPORT, supra note 6, at VII-21 to -22 (courts using contract statute of limitations start period at sale rather than at injury); Note, supra note 19, at 504-05, 509 n.45.

85. Prior to the adoption of the discovery rule, courts started the limitations period on manufacture or sale, generating results similar to those experienced imder statutes of repose. Black's Law Dictionary still equates statutes of limitation witlı statutes of repose. BLACK's LAW DicTIONARY 835 (5th ed. 1979) (statutes of limitation are one form of statute of repose that prescribe period in which an action inust be brought after it accrnes); see also McGovern, supra note 3, at 582-83 (noting the terms are very often used intercliangeably).

86. See, e.g., Moss, 522 P.2d at 624 (statute of limitations begins on injury for products liability actions); Martin v. Patent Scaffolding, 37 Wash. App. 37, 42, 678 P.2d 362, 365 (1984) (statute of limitations begins on discovery of injury for products liability); $c f$. Birnbaun, "First Breath's" Last Gasp: The Discovery Rule in Products Liability Cases, 13 Forum 279, 282-89 (1977) (action assumed to "accrue" upon injury under the discovery rule); Note, Repose for Manufacturers: Six Year Statutory Bar to Products Liability Actions Upheld-Tetterton v. Long Mfg. Co., 64 N.C.L. REv. $1157,1168 \mathrm{n} .69$ (1986) (action accrues under discovery rule when injury is or should have been discovered).

The discovery rule constrnes accrual as the point at which the plaintiff could first bring the action to a successful conclusion and holds, therefore, that the plaintiff does not have a coinplaint that has accrued until he is aware of the injury. Id. at 281-82. As courts began to adopt thic discovery rule, actions in tort quickly became the preferred method of recovery.

87. See Urie v. Thompson, 337 U.S. 163, 169-70 (1949) (inequity of barring plaintiff with delayed manifestation disease before discovery of harm deinands that statute of limitation does not begin until injury).

Over the years, courts adopted different limitations rules for different actions. In delayed manifestation disease cases, for instance, the "first breath" rule started the statute of limitation on first contact with the defective product, Birnbaun, supra note 86 , at 283-84, whereas the "last exposure" rule began after the plaintiff's last contact with the defective item. See Waters v. Armstrong World Indus., 773 F.2d 248, 249 (9th Cir. 1985). In delayed manifestation eases, therefore, the plaintiff's action might be barred before slue even knew she was injured. See McGovern, supra note 3, at 586. By the time doctors diagnosed the injury, the statute already inay have run. Id.; Dworkin, supra note 12 , at 609 \& n.38 (discovery rule adopted to allow plaintiffs witl delayed inanifestation injuries to recover).

For a proposal designed to alleviate the luardships imposed by statutes of repose on plaintiffs with delayed manifestation diseases, sec Developments in the Law-Toxic Waste Litigation, 99 HARV. L. REV. 1458, 1602-16, 1607 n.24 (recommending that courts extend the discovery rule to define "accrue" as not only discovery of injury, but also discovery of injury's causal connection to 
Statutes of repose incorporate a limitation period that extends from the time of manufacture througli a legislatively determined period, independent of the time of injury. ${ }^{88}$ By starting the linitations period at the time of manufacture, statutes of repose negate the advances made by the discovery rule. As a result, an individual can liave a cause of action barred even before suffering an injury. ${ }^{89}$ Because such statutes can bar claims before they arise, courts typically view these laws as substantive rather than procedural. ${ }^{90}$ Whereas statutes of limitation define when recognized rights will be lost, statutes of repose determine if the right will be recognized at all.91

So althougli statutes of repose and limitation may have had similar purposes prior to the adoption of the discovery rule, they now serve two entirely different functions. Cetainly, both of these statutes are intended to prevent stale claims and avoid the evidentiary difficulties such claims can cause. Statutes of limitation, lowever, prevent the plaintiff from de-

defendant). See also Wilder v. Amatex Corp., 314 N.C. 550, 336 S.E.2d 66 (1985) (statute of repose does not apply to delayed manifestation diseases). But cf. Note, supra note 19, at $512 \mathrm{n} .59$ (observing that under new Washington law, statute starts to run on discovery of injury alone rather than after plaintiff learned of all elements of action).

88. See Note, supra note 86 , at $1160 \mathrm{n} .20$ (statute of repose typically defined as time limit that runs imdependent of action's accrual or injury itself).

89. See Stutts v. Ford Motor Co., 574 F. Supp. 100, 102, 105 (M.D. Tenn. 1983) (injury sustained on 16-year-old tractor barred by application of Tennessee's 10-year statute of repose); Hinton v. Tennessee River Pulp \& Paper Co., 510 F. Supp. 180, 181-82 (N.D. Ala. 1981) (claim for injury incurred while painting allegedly defective transformer 19 years after manufacture barred by same Tennessee statute); Wilson v. Dake Corp., 497 F. Supp. 1339, 1340 (E.D. Tenn. 1980) (despite possibility that manufacturer had continuing duty to warn customer of dangers of product, claim fails because Tennessee Act bars all product liability claims brought after 10 years from date of first purchase); Daily v. New Britain Mach. Co., 200 Conn. 562, 569, 512 A.2d 893, 899 (1986) (products hability claim under Connecticut statute failed because defendant parted with possession/control of product more than 10 years prior to filing of complaint).

90. See Jenkins v. Armstrong World Indus., 643 F. Supp. 17, 25 (D. Id. 1985) (holding that statute of repose is substantive for choice of laws purposes), vacated, 820 F.2d 329 (9th Cir. 1987); Regents of Univ. of Cal. v. Hartford Accident \& Indem. Co., 21 Cal. 3d 624, 581 P.2d 197, 205-07, 147 Cal. Rptr. 486 (Cal. 1978) (characterizing statute as procedural); McGovern, supra note 3, at $585 \mathrm{n} .29$; Note, supra note 86, at $1157 \mathrm{n} .4$ (statute of repose functions as substantive limitation while statutes of limitation typically regarded as procedural). This difference is crucial for choice of law purposes. If courts interpreting another state's laws constrned the statute of repose as procedural, then they would be able to use their own limitations period, thereby limiting the effect of the repose provision. FINAL REPORT, supra note 6, at VII-24. See generally Kozyris, Interest Analysis Facing Its Critics-and, Incidentally, What Should Be Done About Choice of Law for Products Liability, 46 Oнго ST. L.J. 569, 581-86 (1985).

But noticc that a statute of repose is not always substantive. If a plaintiff is injured within the statutory time frame but neglects to bring an action until after the expiration of the repose period, then his claim will be barred. But the statute of repose will have functioned as a procedural rather than substantive limitation. Note, supra note 86, at 1161.

91. See Hartford Fire Ins. Co. v. Lawrence, 740 F.2d 1362, 1367 (6th Cir. 1984) (interpreting Ohio law) (statutes of limitation begin after action accrues, whereas statutes of repose prevent action from accruing); Note, supra note 86, at 1161. 
laying commenceinent of a suit once she is aware of her rights, whereas statutes of repose elininate liability altogether whether or not the plaintiff is aware of her cause of action. To coinpensate for this liarsh result, statutes of repose generally provide a longer period during which the plaintiff can initiate a claim. ${ }^{92}$ But statutes of repose are not designed to allow every plaintiff a reasonable time after injury to bring an action. Instead they define a period which allows the inajority of plaintiffs to seek recovery without subjecting inanufacturers to an indefinite period of liability. ${ }^{93}$

\section{B. Arguments in Favor of Statutes of Repose}

Statutes of repose have been justified by those who advocate tort reform as an effective way to deal with injuries caused by aging products. ${ }^{94}$ Such statutes eliminate the so-called "long tail"95 probleins typically associated with older products. ${ }^{96}$ Although this measure is akin to using a fifty pound inallet to swat a fly, ${ }^{97}$ there can be no doubt that extended hability has indeed been eliminated by these provisions. ${ }^{98}$

The insurance industry has persistently lobbied for a himited hability horizon so that they can predict potential losses with greater certainty. .99

92. Most legislatures have adopted repose periods ranging from 6 to 12 years. See Dworkin, supra note 12, at 609 \& nn.41-42 (listing all the states and their respective periods of repose). Statutes of limitation, however, are usually under three years. Cf. Order of R.R. Telegraphers v. Railway Express Agency, 321 U.S. 342, 349 (1944) (statutes of himitations designed to prevent revival of claims that have not been brought until evidence, witnesses, and memories have disappeared).

93. See Daily v. New Britain Mach. Co., 200 Conn. 562, 578-79, 512 A.2d 893, 904 (1986) (occasional hardship inposed by statutes of repose outweighed by benefits of preventing indefinite exposure to hability).

94. See Kozlowski v. John E. Snith's Sons Co., 87 wis. 2d 882, 902, 275 N.W.2d 915, 924 (1979) (suggesting to legislature that they adopt a statute of repose); FINAL REPORT, supra note 6, at VII-21 to -23 (manufacturers cannot accurately predict future habihty rules or exposure, necessitating clear limitation on period of liability); Note, Wilder v. Amatex Corp.: A First Step Toward Ameliorating the Effect of Statutes of Repose on Plaintiffs with Delayed Manifestation Diseases, 64 N.C.L. REv. 416, 437-38 (1986) (statutes of respose designed to address problems associated with older products).

95. "Long tail" is used to describe the open-ended nature of manufacturers' liability. See Dworkin, supra note 12, at $604 \mathrm{n.11}$; McGovern, supra note 3, at 593; Note, supra note 94, at 438; Note, supra note 19, at 503.

96. See McGovern, supra note 3, at 593 (harsh effects of statutes of repose justified by eliminating long tail problem); Note, supra note 19, at 505 (date of sale statutes favor manufacturers by eliminating indefinite liability).

97. Cf. Birnbaum, supra note 86 , at $279-82$ (discussing inequity of linnitations periods which begin before injury).

98. But see infra notes 230-66 and accompanying text (discussing plaintiffs' efforts to use duty to warn claims to elude the statute).

99. See Final REPORT, supra note 6, at VII-22 to -23 (same); INSURANCE STUDY, supra note 71, at 4-92 (statutes of repose eliminate uncertainty surrounding future liability); Note, The Constitutionality of Statutes of Repose: Federalism Reigns, 38 VAND. L. REV. 627, 632 \& nn.40-41 (1985) 
Insurers contend that not only would risk premiums thereby be reduced, but by decreasing the length of time manufacturers are subject to liability, the absolute number of claims and resulting damages would be reduced as well. ${ }^{100}$ Therefore, insurance premiums should decline as the result of fewer claims and an increase in actuarial certainty. ${ }^{101}$ Presumably, lower msurance rates also result im corresponding decreases in consumer prices. ${ }^{102}$

Proponents of statutes of repose contend that such measures deal equitably with the evidentiary difficulties involved in defending suits agamst products manufactured decades earlier. As the causal events in the products hability action recede further into the past, concerns about the availability of evidence begin to emerge. Records are lost, manufacturing plants are replaced, employees retire, and meinories fade. ${ }^{103}$ Although equity may have demanded a rule that mitigated the harsh impact of traditional negligence and breach of warranty actions on plaintiffs, proponents argue that equity similarly requires a modification that returns the system to a point of equilibrium and ceases to subject manufacturers to the almost insurmountable evidentiary difficulties associated with suits involving products manufactured in the distant past.

Similarly, as the gap between manufacture and suit grows, it becomes more difficult to ensure that the jury will be able to identify and apply the technological standards prevailing at the time of manufac-

(statutes of repose allow greater precision in setting insurance rates by elininating long tail problem).

100. Studies indicate that $97 \%$ of all claims are brought within 10 years of the product's manufacture, leading to the conclusion that the typical statute of repose will bar at least $3 \%$ of all actions. See infra uotes 126-28 and accompanying text for a more detailed discussion of the significance of this figure. The cost of defending such suits and the possible damage awards from these claims therefore are eliminated.

101. Research leading to this Note has uncovered no empirical evidence indicating that insurance rates indeed have declined in a particular state in the years following the passage of a statute of repose. See, e.g., FINAL REPORT, supra note 6, at VII-23 (indicating shortened statute of limitation for medical inalpractice in Indiana produced no discernible inpact on premiuns in that state). In general, rates are set nationally and probably will not reflect changes evident in isolated states. See infra notes 132-33 and accoinpanying text (discussing problems associated with statutes of repose).

102. See Note, supra note 86 , at 1162 (greater predictability of damages and liability results in lower premiums and ultinately lower consumer prices).

103. See Daily v. New Britain Mach. Co., 200 Conn. 562, 583-84, 512 A.2d 893, 904-05 (1986) (suits involving older products impose greater evidentiary burdens on litigants); Birnbaum, supra note 86 , at 279 (limitations periods generally intended to prevent stale evidence, faded memories, and lost information); McGovern, supra note 3, at $583 \mathrm{n} .18$, 589-90 (time lag between manufacture and sale diminishes availability of evidence); Special Project, supra note 19, at 653 (stale suits cause difficulty in terms of availability and admissability of evidence); Note, supra note 86, at 1162 (evidence becomes less reliable with time, making it inore difficult to disprove the assertion of a defect); Note, supra note 99, at 632 (stale clains encounter numerous evidentiary difficulties); Note, supra note 19, at 504 (tinne limitations on clains protect defendants from evidentiary problems as records are lost and ineinories fade). 
ture. ${ }^{104}$ Juries often are tempted to apply current industry standards and practices to the defendant's past manufacturing practices. As a result, subsequent improvements in product safety create the impression that past methodologies were flawed and that the product, therefore, was defective. By reducing the time between manufacture and trial, such measures increase the likelihood that the jury will examine the defendant's conduct using the appropriate technological standard. ${ }^{105}$

Courts and commentators further claim that statutes of repose protect the reasonable expectations of manufacturers who rely on the passage of time as an imdication of non-liability. ${ }^{106}$ Manufacturers contend that businesses must be able to plan their affairs without constant concern about potential hability for their older products. ${ }^{107}$ An explicit delimitation of the period of hability would allow businesses to devote their

104. See Daily, 200 Conn. at 583-84, 512 A.2d at 904-05 (in suits concerning older products, temptation for jury to apply subsequent technological standards).

105. See Schwartz, supra note 19, at 843 (statutes of repose help decrease impact of so-called "hindsight liability"); Note, supra note 99, at 632, $633 \mathrm{n} .44$ (statutes of repose dinninish problems associated with advancing technology by simply limiting the time between manufacture and suit); Special Project, supra note 19, at 653 (statutes of repose lessen variance betwcen current technological standards and the standard at time of sale by decreasing time differential).

One must question the simcerity of the legislatures and courts in expressing concern for evidentiary difficulties, given that exceptions to statutes of repose are made commonly for victims of delayed manifestation diseases. See, e.g., TENN. CODE ANN. § 29-28-103(b) (1980) (creating exception to statute of repose for asbestos claims). It is not clear whether victims of products such as asbestos or DES receive an exemption because they elicit more sympathy, comprise a greater number, or because the causal connection between product and injury is more certain. See, e.g., Dworkin, supra note 44, at 45 (statutes of repose meant to address problems associated with old products, not delayed manifestation diseases). Although legislatures enacted statutes of repose to remedy problems associated with old tractors and not delayed manifestation diseases, any justification for these statutes must address why evidentiary problems are considered overwhelming for one class of plaintiffs but not the other, even though the time differential involved is similar. Some commentators have suggested that the availability of workers compensation for injuries caused by capital goods justifies the distinction. See id. This position does not explain, however, why those persons not covered by such programs should have their claims barred. Connecticut, for exainple, provides an exemption from its 10-year statute of limitations for victims of asbestos and those not compensated under the state's workers compensation statute. CoNN. GEN. STar. $\$$ 52-577a(c), (e) (Supp. 1989).

106. Daily, 200 Conn. at 584, 512 A.2d at 905 (purpose of statutes of repose is to protect people who have relied on passage of time without any claims being made and planned their affairs accordingly). One certainly ean question, however, whether the manufacturer of capital goods can justifiably rely on the passage of time as an indicator of non-liability. Capital products often are designed to last for well over a decade. Should courts rcally protect the reliance of such manufacturers on the mere passage of time as indicating freedom from liability? If anything, such manufacturers should be well aware of potential liability and, as a result, should be expected to take greater precautions not only in manufacturing and testing of their products, but also in retaining and preserving records to be used in defense of their product at some point in the future.

107. See McGovern, supra note 3, at 593 (extended hability negatively impacts business' ability to plan); Note, supra note 99, at 633 (greater precision in setting insurance rates should improve business' ability to plan). 
full resources to productive activities rather than retaining them as a precaution against unforeseen liability.

Finally, proponents of statutes of repose argue that the legislature, rather than the judiciary, is in the best position to weigl the competing interests involved in this dehicate area of liability. Legislative committees can objectively assess information regarding the number of putative plaintiffs that might be affected by a particular repose provision and then balance this information against concerns about the actual need for reform and the effect any such measures would have on insurance rates and the business climate. In response to criticisms concerning those persons not injured withm the legislatively determined time frame, proponents point out that all statutes of limitation involve drawing a somewhat arbitrary line which necessarily excludes those claims falling just after the point of demarcation. ${ }^{108}$ They conclude that legislatures in their factfinding capacity are best able to strike an equitable balance between allowing the majority of clamiants to have their day in court and ensuring that defendants do not face unbounded liability. ${ }^{109}$

\section{Arguments Against Statutes of Repose}

Except in topsy-turvy land, you can't die before you are conceived, or be divorced before ever you marry, or harvest a crop never planted, or burn down a house never built, or miss a train running on a non-existent railroad. For substantially similar reasons, it has always heretofore been accepted, as a sort of legal "axiom," that a statute of himitations does not begin to run against a cause of action before that cause of action exists, that is, before a judicial remedy is available to the plaintiff. ${ }^{10}$

While statutes of repose have gained widespread legislative acceptance, they lave received almost umiversal criticism in the academic community. Statutes of repose liave been attacked on nunierous public policy grounds and clallenged constitutionally in virtually every state in which they have been enacted. ${ }^{111}$ Althougli nost have survived constitu-

108. See Mathis v. Eli Lilly \& Co., 719 F.2d 134, 140 (6th Cir. 1983) (interpreting Tennessee law) (any statute of limitation imvolves line-drawing and corresponding lardships); McGovern, supra note 3, at 594 (line-drawing inevitably results in some inequity for those cases around the line).

109. See Special Project, supra note 19, at 653 (legislatures' capacity to gather data and assess policy concerns make it appropriate branch to set repose period); $c f$. McGovern, supra note 3, at 596 (legislatures theoretically better equipped and more adept at obtaining information and gathering feedback, but in practice rely on emotion rather than analysis).

110. Dincher v. Martin Firearms Co., 198 F.2d 821, 823 (2d Cir. 1952) (Frank, J., dissenting) (footnotes omitted).

111. Although few state conrts actually lave decided that statutes of repose contravene either state or national constitutional provisions, but see Lankford v. Sullivan, Long \& Hagerty, 416 So. $2 \mathrm{~d}$ 996 (Ala. 1982) (10-year limitation arbitrary and therefore unconstitutional), the attacks lave been 
persistent and pointed. This area, however, has been examined extensively elsewhere in the scholarly literature, and accordingly this Note will devote only a short word to the general points asserted.

The constitutional attacks inounted against statutes of repose have been concentrated in three areas: equal protection, due process, and state constitutional guarantees of judicial redress, or "open courts" provisions. The majority of courts have concluded that open courts provisions guarantee a judicial remedy only for recognized rights of action. Although statutes of repose prevent a cause of action from arising, they do not prevent plaintiffs froin bringing an established legal claim. See Mathis, 719 F.2d at 143 (open courts provision apphes only to established legal claims, and legislatures define what claims courts will recognize); Van Den Hul v. Baltic Farmers Elevator Co., 716 F.2d 504, 512 (8th Cir. 1983) (plaintiffs barred by statute of repose have no legally cognizable claim); Stutts v. Ford Motor Co., 574 F. Supp. 100, 102-03 (M.D. Tenn. 1983) (open courts provision binds judiciary not legislature; courts must be accessible only to claims legislature dictates are legally cognizable); Tetterton v. Long Mfg. Co., 314 N.C. 44, 53-54, 332 S.E.2d 67, 72-73 (1985) (must have open access only as to those claims legislature deems legally cognizable); see also Daily, 200 Conn. at 582,512 A.2d at 904 (plaintiff claims statute of limitation bars action before it accrues in violation of Connecticut's open courts provision); McGovern, supra note 3, at 616 (open courts provision evaded by semantics game: no action, no remedy); Note supra note 86 , at $1170 \mathrm{n} .85$ (legislature has complete discretion to decide what constitutes a cause of action); Note, supra note 99 , at $644-48$ (discussing application of open courts clauses in state constitutions to states of repose). But see Kennedy v. Cumberland Eng'g Co., 471 A.2d 195, 198 (R.I. 1984) (statute of repose violates state constitution's open courts provision). These decisions rest on the assumption that the legislature can abolish a common law claim, an assumption that has becn validated by various Supreme Court decisions. See, e.g., Duke Power Co. v. Carolina Env'l Study Group, 438 U.S. 59, 88 n.32 (1978) (no vested right in common law actions; legislature can create or abolish rights despite upset expectations); Silver $\mathrm{v}$. Silver, 280 U.S. 117, 122 (1929) (Constitution does not forbid abolition of common law rights).

Due process claims rest on a similar argument suggesting that statutes of repose deny plaintiffs due process of law in the pursuit of otherwise valid claims against manufacturers. The response of the courts has been similar as well. See Mathis, 719 F.2d at 141 (statute of repose does not violate due process); Buckner v. GAF Corp., 495 F. Supp. 351, 353 (E.D. Tenn. 1979) (same); Dworkin, supra note 44, at 61-65 (pointing out that it is not clear how successful due process challenges will be since most cliallenges have been on equal protection grounds); Note, supra note 99, at 642-44 (discussing three lines of cases that adopt the rational basis test for statutes of repose). In addition, plaintiffs injured days before the statutory bar have claimed the limited time period during which they must bring a claim violates their due process rights. The courts are split on this assertion, some holding that due process is not violated if the majority of complainants are not disadvantaged, see, e.g., Hargraves v. Brackett Stripping Mach. Co., 317 F. Supp. 676, 683 (E.D. Tenn. 1970), whereas others hold that due process inust be determined for each individual plaintiff. Flippin v. Jarrell, 301 N.C. 108, 114-15, 270 S.E.2d 482, 486-87 (1980).

Plaintiffs also have raised equal protection issues by contending that statutes of repose impermissibly distinguish between plaintiffs injured one day before the statutory bar and those injured one day after the bar. See, e.g., Stutts, 574 F. Supp. at 104-05 (plaintiff asserted that Tennessee Products Liability Act would cause hardship on persons who might be injured one day after bar and that the Act failed to distinguish among claims on basis of the product's anticipated useful life, and the statute failed to limit exposure to claims and curb cost of liability insurance); see also Dworkin, supra note 44, at 54-61 (discussing equal protection problems in different types of cases); Note, supra note 86, at 1167 (North Carolina Supreme Court rejected equal protection on chailenges to statutes of repose); Note, supra note 99, at 635-36; cf. Mathis, 719 F.2d at 140 (any statute of limitation involves similar line drawing and corresponding hardships); Daily, $200 \mathrm{Conn}$. at 575, 512 A.2d at 901 (plaintiff claiming equal protection violation on other grounds). A few courts have applied an intermediate level of equal protection review to statutes of repose after concluding that the right to seek redress is an important, if not fundannental, right. See Heatli v. Sears Roebuck \& Co., 123 N.H. 512 , 525-26, 464 A.2d 288, 294-95 (1983) (12-year statute of repose lield unreasonable and not substantially related to legislature's purpose). 
tional scrutiny, ${ }^{112}$ several factors question the continuing wisdom of this particular legislative reform effort.

The primary justification for passing statutes of repose has been the perceived need to address the so-called products hability "crisis." The most damaging argument agamst statutes of repose, therefore, challenges the basic assumption underlying the enactment-that a crisis exists to be remedied. ${ }^{113}$ The Connecticut Supreme Court recently rejected a constitutional challenge to that state's statute of repose premised on the argu-

The majority of courts examining the issue have applied a rational basis analysis, however, holding that neither a suspect class nor fundamental right is involved. See, e.g., Stutts, 574 F. Supp. at 105 (plaintiff and defendant agreed that standard of review was "reasonableness" of classification); Daily, 200 Conn. at 579, 512 A.2d at 902-03 (adopting rational relationship test and holding that legislature's classifications were reasonable and indeed helped solve insurance crisis); see also Note, supra note 99, at 636 (inost recent opinions have adopted rational basis test); Note, supra note 86, at 1166 (North Carolina applies rational basis test). As a result, it is unsurprising to find that such statutes have been upheld as promoting the legitimate state interest of curbing otherwise indefinite hability. See, e.g., Stutts, 574 F. Supp. at 105 (statute rationally related to ending liability 10 years after manufacture); see also Note, supra note 99 , at $638 \mathrm{nn} .88$ \& 89 (courts have found legitimate state purpose in limiting hability). But see Lankford, 416 So. 2d at 1004 (holding that statutes of repose fail rational basis test due to arbitrary results). However, the court's conclusion in Stutts, 579 F. Supp. at 105 , that a statute eliminating hability 10 years after manufacture is rationally related to the goal of ending liability 10 years after inanufacture, is somewhat tautological. The court should have examined the underlying rationales of the statute, including the evidentiary concerns involved with older products, and balaneed these against the equitable interest of innocent plaintiffs before upholding the validity of the statute. The court also might have tested the assertion that unlimited hability generated a crisis deinanding a legislative response.

Some commentators have maintained that statutes of repose create an "irrebuttable presumption" that all products have the same statutorily mandated, useful life (the repose period can be seen as a statutory approximation of the typical useful life). Such presumptions are disfavored by the Supreme Court. See McGovern, supra note 3, at 620; Note, Date-of-Sale Statutes of Limitation: An Effective Means of Implementing Change in Products Liability Law?, 30 CASE W. RES. L. REV. 123, 149-52 (1979) (if statute involves classification that is not necessary or universally true, court will invahidate); see also Note, The Irrebuttable Presumption Doctrine in the Supreme Court, HaRV. L. REV. 1534, 1556 (1974) (criticizing Supreme Court's view that irrebuttable presumption is denial of due process). A number of states circumvent this difficulty by establishing a rebuttable presumption that the product is not defective after a certain number of years of safe use. See, e.g., Colo. REv. STAT. § 13-21-403(3) (1987) (product rebuttably presumed not defective after 10 years use). See generally Dworkin, supra note 44, at 54-65 (discussing constitutional issues and citing to state court decisions); Note, supra note 99 , at $635-52$ (histing and analyzing state court decisions on constitutionality of statutes of repose).

112. But see Davis v. Dow Chem. Corp., 819 F.2d 231, 234 (9th Cir. 1987) (statute of repose violates fundainental right to pursue wrongful death action); Lankford, 416 So. $2 \mathrm{~d}$ at 1004 (holding that statutes of repose fail rational basis test due to arbitrary results); Kennedy, 471 A.2d at 198 (statute of repose violates state consitution's open courts provision); Heath, 123 N.H. at 526, 464 A.2d at 296 (statutes of repose arbitarily bar actions before they accrue). See generally Note, Product Liability Statutes of Repose as Conficting with State Constitutions: The Plaintiffs Are Winning, 26 ARIZ. L. REV. 363 (1984) (statutes of repose invalidated primarily in states with constitutional guarantees of judicial access).

113. See Daily, 200 Conn. at 580,512 A.2d at 903 (plaintiff challenging constitutionality of statute claims there is no rational relation between act and goal because no real crisis exists); Note, supra note 99, at 634 (statutes of repose unnecessary because insurance crisis does not exist). 
ment that the goal of remedying the imsurance crisis was irrational since there was no crisis to remedy. ${ }^{114}$ While the court agreed that a crisis in products hability no longer existed, it concluded that the legislature had not responded to an illusory demon, but had instead solved the crisis by passing a statute that effectively shielded manufacturers froin unlimited liability. ${ }^{115}$

Today, however, many commentators believe that for most industries $^{116}$ the reportedly insurmountable difficulties associated with obtaining products hability insurance in the 1970s and early 1980s were greatly exaggerated. ${ }^{117}$ In fact, even during the initial storm surrounding the crisis, the presidential task force appointed to study the problem reported that claims regarding the unavailability of insurance were largely overstated.118 Inflated premiums may have resulted from insufficient competition within the insurance industry ${ }^{19}$ rather than unreasonable jury verdicts or extended hability horizons. ${ }^{120}$ One study demonstrated

114. See Daily, 200 Conn. at 580,512 A.2d at 903 .

115. See Daily, 200 Conn. at 580, 512 A.2d at 903 (crisis was deflated by tort reform; to regress would only result in a rekindling of past problems).

116. The drug industry, particularly the firms engaged in research concerning contraceptives and vaccines, is a notable exception. See, e.g., P. HuBER, LIABILITY: THE LEGAL REVoluTion AND ITS CONSEQUENCES 133-34 (1988) (discussing problems in obtaining insurance after discovery of swine flu vaccine); Djeressi, The Future of Birth Control, Wash. Post, Sept. 10, 1989, at C1, col. 1 (citing reluctance of pharmaceutical companies to enter into contraceptive research due to enormous liability potential); Beck, Pressures Chill U.S. Hunt for New Kinds of Contraceptives, Chi. Trib., Aug. 28,1989 , at C11, col. 1 (same); see also Traynor, supra note 23, at 368-69 (discussing problems created by strict hability in drug industry); Prosser, supra note 24, at 808-09 (sante).

117. See Johnson, Product Liability "Reform": A Hazard to Consumers, 56 N.C.L. REv. 677, 679 (1978) (contending that insurers' fears were exaggerated); INSURANCE STUDY, supra note 71, at 3-2 (finding no evidence of unavailability); cf. infra notes 130-31 and accompanying text (indicating subjective factors in rate-making may have led to an exaggeration of the crisis); MUPLA, supra note 13 , $\S 110,44$ Fed. Reg. at 62,733 (manufacturers' concerns about older products may have been overstated, considering vast majority of imjuries occur well within typical 10-year statute of repose); McGoveru, supra note 3, at 595 \& $\mathrm{n} .96$ (problems with extended liability probably overstated). But see Rowe, Study on Paths to a "Better Way": Litigation, Alternatives, and Accommodation, 1989 DUKE L.J. 824, $845 \mathrm{n.73}$ (citimg recent studies indicating that liability crisis is ongoing, resulting in unaffordable insurance premiums, discontinuation of product lines, reluctance to introduce new products, and declining research and development efforts).

118. INSURANCE STUDY, supra note 71, at 3-2 (unavailability neither a severe nor widespread problem). But see FINAL REPORT, supra note 6, at V-17 to -19 (acknowledging significant increases in premiums during the mid-1970s).

119. See Dworkin, supra note 12, at 619 \& n.106 (rates have stabilized in part due to increase in competition); $c f$. Schwartz, supra note 19, at 847 (competition now exists in industry making statutes of repose unnecessary).

120. Professor Schwartz has indicated that an inexhaustive review of the case law revealed only one recent case that he perceived as imposing liability in questionable circumstances. See Schwartz, supra note 19, at 847 n.313. Oddly, Professor Schwartz, who in his later published articles questioned the need for reform, served as Chairman of the on Product Liability and Accident Compensation, which recommended reform efforts. See MUPLA, supra note 13, introduction, 44 Fed. Reg. at 62,715 . 
that insurance costs as a percentage of sales remained relatively stable at approximately one percent from 1963 through 1983.121 In fact, although product liability premiums rose rapidly, they were largely in line with increases in other areas of the insurance industry such as automobile rates, which increased over $350 \%$ during the same period. ${ }^{122}$ Insurance compamies base premiums, at least in part, on subjective judgments, and some evidence suggests that they may have been reacting more to economic fluctuations, poor investment decisions, or simply self-induced paranoia than to reakistic concerns about expanding liability. ${ }^{123}$

The debate surrounding the existence or non-existence of an insurance crisis will neither start nor end here. ${ }^{124}$ Credible arguments have been inade on both sides. ${ }^{125}$ What should be noted, particularly by legislatures contemplating revisions in products liability statutes, is that the existence of an insurance crisis is still largely in doubt and the severity of the problem varies greatly from industry to industry. ${ }^{126}$

Even if one assumes that there is an insurance crisis demanding reform, several other factors undercut the ability of statutes of repose to adequately address the problem. First, the insurance industry must demonstrate that statutes of repose will reduce the number of suits against older products by himiting the period in which plaintiffs can bring claims. In actuality, only a very small percentage of suits involve older products. Some studies indicate that as many as ninety-seven percent of all product related injuries occur withm the first six years following manufacture. ${ }^{127}$ Although proponents may use tlis figure to suggest that relatively few plaimtiffs will be affected adversely by a typical ten-year statute of repose, the figure also suggests that many of the arguments in favor of statutes of repose may be overstated. If only three percent of all

121. See Schwartz, supra note 19 , at $812-13$.

122. Id.

123. See Dworkin, supra note 12, at 602-03 n.4 (premiums more a response to actuaries' subjective judgments concerning the state of economy and company investment decisions, rather than reaction to jury verdicts); FinAl REPORT, supra note 6, at VII-23 (even small number of cases involving older products have disproportionate impact on rates due to subjective nature or ratesetting).

124. See L.A. Times, Sept. 26, 1989, § 1, at 2, col. 6 (discussing district court disposition of suit brought by 19 state attorneys general against a group of insurance companies); Maryland Attorney General Joins Others Suing Insurers, Wash. Post, June 15, 1988, at F1, col. 1.

125. Cf. Rowe, supra note 117 , at $839-47$ (discussing both sides of the "litigation explosion" debate).

126. INSTITUTE FOR CIVIL JUSTICE, ANNUAL REPORT $89-90$ (1989) (indicating rapid rise in number of suits involving asbestos and pharmaceuticals but smaller increases in other industries).

127. See MUPLA, supra note 13, $\S 110,44$ Fed. Reg. at 62,733 ; see also Schwartz, supra note 19, at $846 \mathrm{n} .307$ (insurers have not proven that older products generate high volume of cases). 
claims are eliminated by a six-year repose period, then the efficacy of such statutes undoubtedly is called into question. ${ }^{128}$

Insurers respond that a small percentage of claims result in a disproportionate share of damages. ${ }^{129}$ Yet the insurance industry has failed to demonstrate that suits against older products actually are responsible for a proportionately larger share of damage awards. Unless insurance coinpanies can demonstrate that suits brought later in a product's life involve a significant proportion of plaintiffs or result in a disproportionate percentage of all damages paid, then the conclusion that statutes of repose can do little to decrease the hability burden seems inevitable.

Insurers, however, contend that even if a small number of claims against older products do not generate a disproportionate share of dainages, they still can have a marked impact on premiums due to the subjective nature of rate-setting. ${ }^{130}$ They claim that statutes of repose should constrain industry fears and result in a stabilization or decrease in rates. Yet given the elaborate analytical mechanisms used by the insurance imdustry today, it is hard to fathom that their predictive abihty is so poor and the uncertainty so great that the system has been thrown into a state of chaos. ${ }^{131}$ The insurance lobby, therefore, appears to have convinced both state and national legislatures that reform measures are needednot to limit the actual number of claims, but rather to reassure the industry and constrain its own unfounded fears about potential liability.

Assuming arguendo that statutes of repose effectively limit the number of product liability claims, it remains doubtful whether manufacturers within a state that has passed a repose statute would experience any benefit in the form of decreased premiums. Insurance rates for products liability are set on a national rather than state-by-state basis, thereby mitigating the beneficial impact states might hope to achieve by passing

128. See Mathis v. Eli Lilly \& Co., 719 F.2d 134, 139 n.10 (6th Cir. 1983) (questioning the effectiveness of statutes of repose in effecting decrease in insurance rates); Stutts v. Ford Motor Co., 574 F. Supp. 100, 105 (M.D. Tenn. 1983) (stating in reference to Tennessee's statute of repose, "the Act in itself will not effect lower premiums"); Note, supra note 19, at 513 (small number of claims barred not enough to impact insurance rates).

129. See Note, supra note 19 , at 513 n.68 (manufacturers and insurers cite statistics indicating $14.2 \%$ of payments made to $4.8 \%$ claimants).

130. McGovern, supra note 3, at 593 (proponents claim that small number of cases have disproportionate impact on insurance rates by creating uncertainty resulting in the imposition of premiums based on "judgemental" reasoning rather than sound statistical analysis); see also supra note 123.

131. See INSURANCE STUDY, supra note 71, at 4-92 (statutes of repose lead to greater certainty in establishing insurance rates); Schwartz, supra note 19, at 847 (noting that the Commerce Department study adopted repose in effort to decrease insurers' expectations concerning potential liability, thereby reducing insurance rates); Note, supra note 19, at 514 (insurance rates set subjectively; statutes of repose intended to affect perceptions of insurance industry regarding potential losses by eliminating extended liability). 
statutes of repose. ${ }^{132}$ As a result, state legislatures may disadvantage instate plaintiffs while deriving no corresponding benefits for in-state manufacturers. ${ }^{133}$

Another drawback of a statutorily defined time limit is that statutes of repose simply lack the flexibility to deal effectively with products of varying anticipated hives. ${ }^{134}$ The inflexible statutory framework fails to recognize inherent differences among products, and differences in the time at which product defects becoine apparent. ${ }^{135}$ The typical ten-year statute of repose, for example, will provide very hittle protection for manufacturers of nondurable items with anticipated lives of less than ten years because such products are unlikely to be in use and cause injury after the expiration of the repose period. Hence the benefits of these statutes will mure primarily to inanufacturers of durable, capital goods.

Some states have atteinpted to use an abbreviated statute of limitation within a ten-year statute of repose to protect inanufacturers of products with a useful hife which is less than the repose period.136 If the statute of repose did not include this inner two- or three-year statute of limitation, then plamtiffs injured one year after manufacture would have nine years in which to bring an action. Such statutes, however, only serve to return nondurable manufacturers to their pre-statute of repose status. Therefore, even with such innovations, nondurable manufacturers receive hittle (if any) benefit from statutes of repose and accordingly experience few of the anticipated insurance benefits.

Not ouly do statutes of repose fail to address the differences among products, they also fail to account for what should be the expectations of manufacturers regarding potential liability. At purchase, the expectations of both parties will embody a generalized conception about the length of time the product will render service. Intertwined with these

132. See MUPLA, supra note 13, introduction, 44 Fed. Reg. at 62,711 (Inodel act needed because national rate-1naking limits the effect of state-by-state reform measures); McGovern, supra note 3 , at $595 \& \mathrm{n} .97$ (insurance rates are set nationally, making it unlikely that states will receive benefit froin passage of statutes of repose); Note, supra note 19, at 514 (rates set nationally prevent in-state benefit from passage of statutes of repose).

133. The effectiveness of statutes of repose is similarly undermined by variations among states that create the possibility that choice of laws provisions may dictate the use of another statc's substantive law on products liability. See generally Kozyris, supra note 90, at 583-87.

134. See Note, supra note 19, at 508 (statutes of repose fail to account for variance in amount of use across products).

135. Statutes of repose inight be warranted if extended use without injury indicated a non-defective product. But this simply is not true. A defect in a tractor trailer may manifest itself immediately or may not become evident until a certain set of circumstances combine at soine point in the future. See Schwartz, supra note 19, at 844; see also supra notes 56-59 and accompanying text (discussing cases rejecting prolonged use without injury as indicative of non-negligent manufacture).

136. See, e.g., Ala. CODE \$ 6-5-502(a)(1), (2)(c) (Supp. 1989) (I and 10 years); IDAHo Code \& 6-1303(2), (3) (Supp. 1989) (2 and 10 years). 
expectations is an implicit understanding tliat if the product contains a defect and is therefore unreasonably dangerous, then the purchaser will be able to seek redress from the manufacturer. Manufacturers calmot justifiably express surprise or claim unfairness when injured parties ultimately bring suit. Presumably, a manufacturer of imdustrial machinery understands that her product is designed to last for at least a decade and perhaps much longer. She must realize at the poimt of sale, therefore, that suits may be brought against her at any time in the course of that product's life.

Statutes of repose place the burden of injury not on plaintiffs generally, but on those individuals unfortunate enough to be injured after the expiration of the repose period. Althougl evidentiary concerns legitimately may argue in favor of using statutes of limitation to bar a cause of action when a plaimtiff has allowed a valid claim to go stale, the argument loses persuasive force when an innocent plaintiff is imjured and files withim a reasonable period of time, but then is demied the opportunity to bring his case to court. ${ }^{137}$

Although proponents of reforn often complain about the evidentiary burdens imposed on manufacturers when defending suits against older products, ${ }^{138}$ they fail to recognize that manufacturers are in the best position to preserve whatever evidence they miglit need to defend a suit at some later point in time. By maintaining design and production records, customer hists, component part specifications, etc., manufacturers can ensure that all necessary evidence is available at trial. More importantly, plaintiffs still have the burden of proving any defect, ${ }^{139}$ and as a result they bear much of the hardship caused by evidentiary obstacles.

Perhaps the fundamental problen with statutes of repose is that in the hurried attempt to limit manufacturers' hability, state legislatures have failed to analyze the impact their reforms have on the strict liability system. ${ }^{140}$ Assuring compensation for plaimtiffs injured by defective products, spreading of hability costs across all those at risk, and creating incentives for safety consciousness all are undermined by the passage of statutes of repose. ${ }^{141}$ Statutes of repose arbitrarily leave injured individuals without a remedy by discontinuing liability regardless of whether the

137. See Note, supra note 19 , at 519 (statutes of repose punish innocent plaintiffs, not simply those not diligent in filing).

138. See supra note 103 and accompanying text.

139. See Victorson v. Bock Laundry Mach. Co., 37 N.Y.2d 395, 404, 335 N.E.2d 275, 279, 373 N.Y.S.2d. 39, 44 (1975) (passage of time complicates plaintiff's burden of proving defect); Note, supra note 19, at 506 n.25 (same).

140. See supra notes $38-41$ and accompanying text (discussing purposes of strict liability).

141. See Dworkin, supra note 44 , at 42 (statutes of repose destroy justifications for strict liability). 
plaintiff can effectively demonstrate that a product defect caused the injury. As a result, the costs of injury are not spread over all those at risk, leaving many users unprotected and subject to the possibility of suffering a crippling injury without suitable recourse.

Moreover, by truncating the period of liability, statutes of repose eliminate a powerful economic incentive for a inanufacturer to improve the long term quality and safety of his product. ${ }^{142}$ Although the market may provide some incentive to produce a safer product, experience has shown that without a inore tangible inotivation in the form of either government regulation or potential habihity, conteinplated safety ineasures often lose out in the balance between measurable, short-term returns and conjectural, long-term reputational gains from product safety. ${ }^{143}$ Accordingly, the threat of potential hability provides a necessary incentive to produce safe goods that will remain safe over the course of their useful hives.

Statutes of repose punish injured plaintiffs, not for delinquency in filing, but rather for suffering an injury at the wrong time. By so doing, these statutes abrogate the defendant's duty to his customer without consideration for the nature of the product or the parties' expectations. ${ }^{144}$ If

142. See McGovern, supra note 3, at 598 (shifting risk of loss to consumer after certain period of time decreases manufacturer's incentive to promote safety); $i d$. at 590,599 (potential liability provides incentive to promote long-term safety without which manufacturers would not make effort to maintain safety); Schwartz, supra note 19, at 845 (statutes of repose not only deny legitimate recoveries, but also result in significant underdeterrence); Note, supra note 99, at 635 (social and economic pressure, not goodwill, force designers and manufacturers to address safety concerns; absolute limitation on liability would reduce incentive to promote long-term product safety).

143. The market undoubtedly exerts some pressure on companies to produce a safe product. But how much safety consciousness does market pressure engender, and is it a societally optimal level of precaution? Without perfect information regarding company safety records, consumer decisions can not reflect an informed choice concerning desired levels of safety. Therefore, firms can devote fewer resources to safety than society desires without any corresponding economic detriment to the firm. In other words, the balance weighs tangible, short-term gain from safety skimping against projected reputational and goodwill gains from safety consciousness. In this circumstance, manufacturers may very well select the former option. Tort law can be seen as an effort to bring this balance into a more appropriate equilibrium. See A. STONE, Economic Regulation AND the Public INTERest (1977). According to Professor Stone:

The free-market model depends ultinately on the assumption that the free market will best satisfy public values through the instrumentality of the invisible hand. Yet the evidence is overwhelming that public values and the goals of firms diverge sharply. Cigarette flrms, for example, felt no need to warn consumers of their product's dangers, nor did automobile manufacturers voluntarily make cars safer. Indeed, the enormous voluine of fraud that the F.T.C. and various federal, state, and local bodies have uncovered points to the inescapable conclusion that when profit and sales goals conflict with public values, the latter must yield in business calculations.

Id. at 266-67. But see Prosser, supra note 23, at 1119 n.142 (indicating that informal discussions with business leaders led to the conclusion manufacturers were more concerned with corporate reputation than liability).

144. See Dworkin, supra note 44 , at 43 (statutes of repose deny defendant has duty to plaintiff based on product age rather than timeliness of complaint). 
in fact extended safe use was indicative of a nondefective product, then such statutes might be justified. For latent defects, however, extended use is entirely consistent with the conclusion that the inanufacturer produced an unreasonably dangerous product. ${ }^{145}$ Statutes of repose shift the burden of avoiding injury from manufacturers, who can test their product and spread the cost of such precautions annong their custonners, to consumers, whose only chance of decreasing the hikelihood of injury is to exercise greater caution. ${ }^{146}$ In sum, plaintiffs with valid clains are denied recovery on the basis of an arbitrary mechanism, which is unrelated to the merits of their clain or the relative fault of the parties, and is in violation of the principles that precipitated the adoption of strict habihty alnıost thirty years ago.

\section{A Return to Judicial Control of the Products Liability Action}

Recognizing that the existence of a crisis is largely in doubt, that insurers have not demonstrated that statutes of repose will have a demonstrable effect on either the number of claims or insurance rates, and that such statutes often have undesirable public policy consequences, it seems reasonable to replace the rigid statutory fornat with the more flexible and equitable powers of the courts. Although proponents of statutes of repose argue that legislatures are in the best position to gather data and balance the competing interests at stake, ${ }^{147}$ they neglect to note that products liability claims are extremely fact-intensive. The trier of fact in a civil proceeding can take into account the type of product involved, its age, the setting in which it has been used, and the kind of defect alleged in determining whether or not liability should be imposed. ${ }^{148}$ All these factors would be probative in determining whether a defect, or simply the passage of time, caused the plaintiff's injury. Soine commentators have suggested that courts can effectively eliminate implausible old claims through the use of either a directed verdict or n1otion to dismiss. ${ }^{149}$ The flexibility available in the courts ensures that blanket legislative formulas do not subvert the purposes of the product liability system. ${ }^{150}$ Plaintiffs

145. See Schwartz, supra note 19 , at $845 \& \mathrm{n} .298$ (for variety of latent defects, extended use simply does not indicate non-defective manufacture, some states exempt latent defects from provisions of repose statutes).

146. See McGovern, supra note 3, at 598 (statutes of repose shift risk of loss to consumer).

147. See supra notes 108-09 and accompanying text.

148. See McGovern, supra note 3, at 596 (courts more flexible and can examine equities of each case on basis of particular facts).

149. See Schwartz, supra note 19 , at 852 (directed verdict and motion to dismiss more effective at dealing with implausible old claims than statutes of repose).

150. Cf. Peck, The Role of the Courts and Legislatures in the Reform of Tort Law, 48 MiNN. L. REv. 265, 296-302 (1963) (no reason for courts to defer to legislatures in area of tort reform on basis of relative abilities). 
injured by demonstratively defective products will be compensated without regard to the fortuitous timing of their injury.

Another factor favoring greater judicial oversight of the products hability area is that courts place the parties on more equal footing than is possible in the legislature. Insurers and businesses are well represented $\mathrm{m}$, and actively lobby, state legislative bodies. ${ }^{151}$ Conversely, plaintiffs injured by manufactured goods are a rather diffuse minority, unlikely to exercise a great deal of influence on such bodies and equally unlikely to enter into the pluralistic compacts that some scholars contemplate will ensure that minority views are represented in the legislative process. ${ }^{152}$ Moreover, once their case has been tried, past plaintiffs have little incentive to express their views to the legislature. The courtroom, in contrast, provides both parties with an equal and timely opportumity to be heard.

\section{USEFUl LIFE STATUTES}

\section{A. The Common Law Foundations of the Useful Life Concept}

1. Product Age and the Strict Liability Action. As discussed earher in this Note, courts im neghigence actions originally presumed that prolonged use of a product without injury meant that the manufacturer was not negligent. Although this posture eventually changed, courts continued to consider the age of the product in their decisional calculus. Cases arising after the evolution of strict products liability reflect a similar attitude toward the age of a product, often relying on age to determine whether a defect or natural deterioration caused the injury. In Farmer v. International Harvester Co., the court concluded that "the age of a product and the length of its use" are important factors in a determination of hability. ${ }^{153}$ Product age can support a reasonable inference concerning the existence of an original defect, and it also can serve as a fairly rehable surrogate for the number of possible intervening causes. ${ }^{154}$ There comes a point, however, at which natural deterioration rather than defective manufacture is the presumptive cause of the injury, ${ }^{155}$ a point at

151. See McGovern, supra note 3, at 596-97 (greater equality in courts than in legislature due to lobbying power of business interests); Peck, supra note 32, at 16 (manufacturers and insurance companies have well-organized lobbies); Shipp, A.B.A. Urges Modest Limits on Lawsuits over Injuries, N.Y. Times, Feb. 18, 1987, at A14, col. 1 (ABA prepared to lobby in Congress for tort reform).

152. See J. ELY, Democracy AND DisTRUST 80-84, 135, 151-55 (1980) (discussing ability or inability of various groups to gain a voice in political process by entering pluralistic compacts with other interest groups); see also Peck, supra note 32, at 16 ("Ordinarily, tort victims do not constitute a well-organized group nor are they brought together by common interests"; "moreover, they have little interest in legislation . . . because it provides no relief to them for injuries already suffered.").

153. 97 Idaho 742, 748, 553 P.2d 1306, 1312 (1976).

154. See Schwartz, supra note 19, at 832-33.

155. Cf. Beadles v. Servel Inc., 344 Ill. App. 133, 146, 100 N.E.2d 405, 411 (1951) (holding that after substantial period of time, negligence should no longer be inputed to the manufacturer, but 
which the link between manufacture and harm has been severed by the passage of time. ${ }^{156}$

2. Useful Life in the Common Law. Outside the context of statutory useful life provisions, courts have long used the concept of "useful life" to determine the point at which natural deterioration, rather than product defect, is the likely cause of an accident. An analysis of useful life puts the product's age into the context of its anticipated period of use. Accordingly, the conclusions a court reaches about two twelve-year-old products will be inarkedly different if the useful life of one is five years and the other thirty. Courts recognize that at some point, products wear out and injuries caused by such products ordinarily should not result in liability. ${ }^{157}$ The presuinption of neghigence normally accorded to the plaintiff in a strict liability action becone less persuasive as time goes on, not only because it becomes more difficult to differentiate defects froin natural deterioration, but also because manufacturer safety measures are less likely to uncover problems that do not manifest themselves for inany years. ${ }^{158}$ At the point at which period of use and useful life begin to merge, the strict hability presumption becomes particularly troublesome.

In Miller v. Bock Laundry Machine Co., a safety device designed to shut down the drying unit when the user opened the door had deteriorated and was no longer operational. 159 An eleven-year-old boy opened the door and placed his arm into the machime which was rotating at

that "[t]he exact interval of time which will be conclusive as a matter of law we are not called upon to decide in this case").

156. See Pryor v. Lee C. Moore Corp., 262 F.2d 673, 675 (10th Cir. 1958), cert. denied, 360 U.S. 902 (1959).

157. See, e.g., Auld v. Sears, Roebuck \& Co., 261 A.D. 918, 918-19, 25 N.Y.S.2d 491, 493 (App. Div. 1941) (holding that manufacturer is not liable for that which simply wears out). Although this presumption may be justified in a fault-based compensation system, we must consider whether the plaintiff injured after the expiration of a product's useful life is really any less deserving of compensation than the plaintiff injured prior to this time. Unless the deterioration is patent, the rationales of the strict liability system are still applicable. The system attempts to compensate those injured by products and to spread the risk of such mjuries among the products' users. The fact that hability is not imposed demonstrates that even strict liability does not make manufacturers the insurers of their products.

Imposing liability after the useful life has expired does not promote the goal of placing the burden on the party best able to minimize risk. Presumably, the manufacturer has done everything possible to ensure a safe product, and the fact that no injury has resulted leads to the inference that the product was non-defective when manufactured for a period extending through its useful hife. The consumer is thus in the best position to minimize risk by exercising caution in the use of older products.

158. As a result, some commentators have suggested that a negligence standard should be imposed on older products. See Comment, A Time-Dependent Model of Products Liability, 53 U. CH1. L. REV. 209, 213-22 (1986); Schwartz, supra, note 19, at 834 (courts should require more hard evidence as product ages).

159. S68 S.W.2d 648 (Tex. 1978). 
nearly $60 \mathrm{~m}$.p.h. His arm was immmediately severed from the shoulder. At trial, the jury returned a verdict for the plaintiff that the trial court set aside by judgment n.o.v. ${ }^{160}$ On appeal, the court found that the product was designed to last for an extended period of time and noted that several of the manufacturer's machimes were still in use after thirty or forty years. ${ }^{161}$ As a result, the court held that despite eighteen years of safe use, the dryer was withm the contemplated performance period, and the manufacturer therefore could be held hable. ${ }^{162}$

Other courts have made similar comments concerning the inference that can be drawn from a product's useful life. For example, in Kuisis v. Baldwin-Lima Hamilton Corp., the court stated that "[t]he age of an allegedly defective product must be considered in light of its expected useful life."163 Common law product liability actions, therefore, have traditionally taken into account not only the age of the product, but also its "useful safe life."164 If a court determines that the useful life has expired, shattering the causal link between manufacture and injury, then presumably the defendant would not be held liable for injuries sustained by the plamtiff. The presumption of defective manufacture traditionally apphed during the product's useful life no longer would be valid.

\section{B. Useful Life as a More Equitable Approach to Tort Reform}

The statutory version of the common law useful life theory received its first official recognition when the President's Interagency Task Force on Product Liability gave the concept a guarded endorsement and later incorporated it into the Model Uniform Products Liability Act (MUPLA). ${ }^{165}$ Several states then passed similar statutes, ${ }^{166}$ and even the

\footnotetext{
160. Id. at 649 .
}

161. Id. at 651 .

162. Id. at 651-52; see also Traynor, supra note 23 , at $369-70$ (if product with useful life of five years breaks within first six months, one can presume defect was responsible).

163. 457 Pa. 321, 336, 319 A.2d 914, 923 (1974).

164. See also King v. Ford Motor Co., 597 F.2d 436, 441 (5th Cir. 1979) (solenoid should work for 30,000-40,000 miles; immediate failure indicates defective manufacture); Farner v. Paccar, Inc., 562 F.2d 518, 524 (8th Cir. 1977) (normal life span of springs five to six years; only one year of use indicated probable defect); Farmer v. International Harvester Co., 97 Idaho 742, 748, 553 P.2d 1306, 1312 (1976) ("[o]f additional relevance are the age of a product and the length of its use ... [and] its expected useful life"); Calvanese v. W.W. Babcock Co., 10 Mass. App. Ct. 726, 734, 412 N.E.2d 895, 901 (1980) (two years of use well within expected life span); Jakubowski v. Minnesota Mining \& Mfg., 42 N.J. 177, 185-86, 199 A.2d 826, 831 (1964) (burden on plaintiff to present evidence "that the expected useful life of the disc had not been exhausted at the time it broke").

165. See MUPLA, supra note $13, \S 110(A), 44$ Fed. Reg. at 62,732 .

166. See ARK. Stat. ANN. 16-116-105(c) (1987) (using expiration of product's useful life as factor in comparative negligence determination); CONN. GEN. STAT. \& 52-577a (1989) (providing useful life limitations period for planitiffs not covered by workers compensation provision); IDAHO CODE $\S$ 6-1303 (Supp. 1989) (establishing rebuttable presumption that useful life expires after 10 years); KAN. STAT. ANN. § 60-3303 (1983) (same); MINN. STAT. ANN. § 604.03 (1988) (expiration 
United States Senate at one time considered, but failed to adopt, a bill containing a useful life provision during debate concerning federal products liability law. ${ }^{167}$ The MUPLA's proposal originated as a response to the equitable, constitutional, and public policy concerns generated by statutes of repose. ${ }^{168}$ By borrowing the useful life concept froin the common law, the MUPLA proposal suggested that law makers could avoid many of the pitfalls associated witl statutes of repose by establishing a variable period of repose that allowed the trier-of-fact greater flexibility in determining the proper period of limitation. ${ }^{169}$ Sucl statutes reject the notion tliat a standard time limitation can adequately or equitably address the variance among products. Instead, the court determines the limitations period by examining the useful life of the product on a caseby-case basis, rather than applying a generic legislative determination. Although the useful life theory added flexibility to the limitations equation, it still created an outer limit on manufacturers' liability. Upon the conclusion of the product's useful life, useful life statutes, like statutes of repose, prevent a plaintiff from pursuing an action. ${ }^{170}$

Yet, ratler than abandon statutes of repose altogetlier, the drafters of the MUPLA adopted what amounts to a synthesis of useful life and repose concepts. Although the Model Act might have allowed a determination of the product's useful life solely by the trier of fact, ${ }^{171}$ it instead presuines a useful safe life of ten years while allowing the plaintiff an opportunity to rebut this presumption. ${ }^{172}$ As a result, the defendant lias the burden of proving that the useful life has expired during the first ten

of useful life is defense to products liability action); TENN. CODE ANN. § 29-28-103 (1980) (action must be brought within 10 years from purchase or 1 year after expiration of useful life, whichever is shorter); WASH. REv. CODE ANN. $\$ 7.72 .060$ (Supp. 1987) (useful life rebuttably presumed to expire 12 years after delivery).

167. S. 2760, 99th Cong., 2d Sess. § 304, 132 Cong. Rec. 12,071, 12,075 (1986).

168. See Dworkin, supra note 44, at 47-48 (MUPLA did not adopt statute of repose because of equitable concerns with barring action before it accrues).

169. See Hodder v. Goodyear Tire \& Rubber Co., 426 N.W.2d 826, 830 (Minn. 1988) (whereas typical statute of repose specifies presumptive period of limitations, useful hife statutes have the trier of fact determine the period); Special Project, supra note 19, at 654 n.482 (noting that useful life statutes add flexibility to the determination of hability); Note, supra note 86, at 1177 (useful life statutes less arbitrary and much fairer); cf. Note, supra note 19, at 508 (since time has different effects on different products, statutes of repose do not adequately address variance).

170. Morse v. City of Toppenish, 46 Wash. App. 60, 65-66, 729 P.2d 638, $41-42$ (1986) (manufacturers not liable if they demonstrate that useful life has expired); McGovern, supra note 3, at 586 (defendant not liable after expiration of useful life); Note, supra note 69, at 169 (interpreting Minnesota and Connecticut statutes as extinguishing liability after expiration of useful life); Note, supra note 86, at I177 (after expiration of useful life all actions should be barred); Note, supra note 19, at 510 (defendant's can avoid hability by showing useful life expired).

171. Cf. Morse, 46 Wash. App. at 66, 729 P.2d at 642 (useful life statute is statute of repose with repose period determined by trier of fact).

172. MUPLA, supra note $13, \S 110(B)(1),(B)(2)(d), 44$ Fed. Reg. at 62,732 (presumption that useful life has expired after ten years rebuttable by clear and convincing evidence). 
years following manufacture, whereas after that point the plaintiff must demonstrate that the useful life of the product has not expired. ${ }^{173}$

This statutory version of useful life alters the common law in several significant respects. Under the common law, the age of the product is one factor to be considered in determining liability, whereas the statutory construction mandates that age is the factor controlling the plaintiff's opportumity to recover. This distinction has more than superficial significance for imjured parties.

Implicit in the principle that age is the exclusive factor to be considered is the assumption that after the product's anticipated life has expired, natural deterioration rather than product defect caused the injury. Yet this assumption is not a controlling precept of the statute. Under the common law analysis the trier of fact must actually find that the product failed because of wear and tear. Under a useful hife statute, the plaintiffs claim will be barred after the expiration of the product's life even if he can conclusively demonstrate that an orignial defect caused the accident and that product deterioration had nothing whatsoever to do with the inalfunction. The statute sets an outer himit on liability regardless of the basis for the action and despite the fact that product deterioration was not actually the cause of injury. Useful life provisions have this effect not simply because the concept has been placed in statutory forin, but because useful hife statutes are a substitute for traditional statutes of limitation, not statutory enunciations of common law liability principles.

Useful life statutes do not simply elevate the age of the product to a level of paramount importance. They also narrow the range of issues which the jury examines by focusing the jury's attention on determining whether the product was within its anticipated lifetime when the accident occurred. Counsel for the defendant no longer must convince the jury that the age of the product is an important factor for their consideration. Instead the law lends credence to the contention, and requires that the jury first address the issue of the product's age before assesing liability. ${ }^{174}$

Whereas common law courts may have paid lip service to the notion that liability should be discontinued after the expiration of the product's useful hfe, a statutory provision ensures that the court's language is more than mere rhetoric. Even though courts often invoked the useful life lan-

173. See Note, supra note 19 , at 511 (interpreting Washington's statute as providing opportunity for defendant to rebut presumption of 12 years useful life before 12-year mark and providing plaintiff opportunity to rebutt presumption after 12 years).

174. See MUPLA, supra note 13, $\S 110(A), 44$ Fed. Reg. at 62,733 (placing useful life in statutory form ensures both judge and jury will give it serious attention). 
guage, there are very few cases in which the trier of fact actually found for the defendant because the product fell outside its useful safe life. ${ }^{175}$

Studies showing that the vast majority of products liability claims are brought within a few years after manufacture raise questions about the need for useful life statutes as well as statutes of repose. ${ }^{176}$ The effect of this observation for useful life provisions, however, is not nearly as damaging as for statutes of repose. If, for example, ninety-five percent of all products hability claims are brought within ten years of manufacture, then a ten-year statute of repose would bar ouly five percent of these actions. In contrast, a useful life provision would prevent claims brought against products with useful lives of less than ten years as well as those with useful lives in excess of ten years and, therefore, would bar a greater number of actions. ${ }^{177}$

The overriding advantage of useful life statutes is that, unlike statutes of repose, they provide an equitable and rational limitation on manufacturers' exposure to hability. ${ }^{178}$ Therefore, even if further study demonstrates that the much ballyhooed "insurance crisis" was illusory or reform ineasures do not bar a significant number of claims, useful life provisions still establish a reasonable limitation on hability without regard to their effectiveness as a means of tort reform. Useful life statutes discontinue hability not on the basis of a "one size fits all" statutory time limitation, but rather at the point at which the causal nexus between inanufacture and injury is more logically and equitably severed-the conclusion of the product's useful life.

While statutes of repose defeat the expectations of consumers, useful life statutes represent a reasonable approximation of the parties' expectations concerning durability. Purchasers expect a product that will function safely and effectively durmg its lifetime. If the product is defective

175. However, in Jakubowski v. Minnesota Mining \& Mfg., 42 N.J. 177, 185-86, 199 A.2d 826, 831 (1964), the court presumed that the useful life of a sanding disc had expired because the plaintiff did not show the disc was within its useful hife. The court noted that such discs wear out and can cause injury if used beyond that point. Because the plaintiff failed to deinonstrate the product was within its useful life, the court held for the defendant. See also Auld v. Sears, Roebuck \& Co., 261 A.D. 918, 918-19, 25 N.Y.S.2d 491, 493-94 (App. Div. 1941), aff'd, 288 N.Y. 515, 41 N.E.2d 927 (1942) (court holds manufacturer not hable for parts that simply wear out presumably because they are beyond their useful life).

176. See Note, supra note 19, at 513 (considering small number of claims affected, impact on insurance rates unlikely) (basing analysis on INSURANCE SERviCES OFFICE, 1976 Product LIABILITy Closed Claim Survey: A Technical aNalysis of SuRvey Results 81-83 (1977)).

177. Tennessee has taken measures to eliminate this problein by wrapping its useful life provision within a ten-year statute of repose cap to provide protection for inakers of products with useful lives of less than ten years. See TENN. CODE ANN. \$ 29-28-103(a) (1980).

178. See Berry v. Beech Aircraft Corp., 717 P.2d 670, 681 (Utah 1985) (recommending useful life statute as more equitable approach to product liability reform); INSURANCE STUDY, supra note 71 , at 4-91. 
and results in injury, then the purchaser anticipates that she will be able to pursue an action against the inanufacturer. During the period of anticipated use, this expectation is reasonable. Upon the expiration of the product's useful life, however, the expectation of continued liability no longer is justifiable. The consumer should discard the product or continue using it at her own risk. ${ }^{179}$ The legislature, therefore, legitinately may elininate liability beyond the product's useful life from both an expectational and equitable perspective.

Further, unlike the devastating consequences statutes of repose have on the traditional rationales for strict liability, useful life statutes remain loyal to the purposes of the tort system. Useful life provisions continue to allow cost spreading among those at risk; they retain the incentive to produce safe goods throughout the product's lifetine; and they provide coinpensation for all plaintiffs with valid claims. Granted, the contention that useful life statutes compensate all plaintiffs with "valid" clains is somewhiat conclusory and self-fulfilling. Depending on how one defines "valid," the goal of compensating injured plaintiffs could be satisfied by virtually any system of hability. Yet the assumption that the passage of time severs the causal nexus between inanufacture and injury is rational and ensures that sympathetic juries do not impose liability for injuries from worn out products. As a result, labeling claims within the period of useful life as "valid" and those without as "invalid" seems similarly justifiable.

Although useful life provisions inaintain strict liability's aim of providing a form of societal insurance for all those at risk from defective products, the doctrime excludes those individuals injured after expiration of the product's useful life from the benefits of this risk-spreading. Yet any provision which limits the period in which manufacturers can be leld liable will necessarily result in some hardship on those excluded by the change. The flexibility inlerent in the useful life determination, however, should minimize the costs of reform. Moreover, the concept unquestionably represents a significant advance over the arbitrary liability cut-off established by statutes of reposes. Still, legislatures may wish to provide some form of limited relief for individuals injured at this time and law inakers slould be cognizant of the fact that tort reform is not witlout its costs. ${ }^{180}$

179. See ARK. STAt. ANN. $\S 16-116-105$ (c) (1987) (use beyond useful life is a factor in calculating comparative fault).

180. It is important to recall that in 1965 , Chief Justice Traynor emphasized that strict liability was designed solely as a compensatory mechanism. He suggested that courts should resist the inevitable inflationary pressures on awards and the inclusion of damages for pain and suffering. Without such resistance, he warned that the cost of maintaining strict liability could become prohibitive. He also stated that plaintiffs should be free to pursue damages for pain and suffering if they were willing 
Although in theory useful life provisions strike an equitable balance between liniting manufacturers' liability and providing a remedy to injured individuals, they are not necessarily a panacea for this troubled area of the law. ${ }^{181}$ The practical difficulties involved in their application are forboding and complex, and only a few cases under existing useful life statutes have dealt with these issues in a systematic fashion. Questions arise concerning several issues, including the method for calculating useful life, the possible adverse effects on manufacturer incentives to $\mathrm{m}$ crease durability, the res judicata imphications of a determination of useful life in one trial on subsequent suits, and the notice problems associated with a himitations period which cannot be determined without resort to trial. Each of these issues will be addressed in turn.

\section{The Calculation of Useful Life}

The main problem with useful life statutes lies in the choice of criteria for deternining the length of a product's useful life. Should the period of repose $\mathrm{e}^{182}$ be defined by the useful life of the specific product involved in the accident, of all such products manufactured by this defendant, or of all similar products on the market? ${ }^{183}$ If one of the latter two standards is used, should the deternination be based on the average life or the longest known life of the product, or should the time be chosen arbitrarily from a bell-curve at a point where, say, eighty-eight percent of all similar products have worn out? If instead the useful hife is to be determined for the particular product at issue, what factors should be considered?

Among the states that have adopted useful hife statutes, several have offered exphicit criteria for arriving at a determination of useful life, ${ }^{184}$ while others have simply stated that liability is to be discontinued upon the expiration of the product's useful life without providing any further

to prove negligence on the part of the manufacturer rather than simply relying on the existence of a product defect. Traynor, supra note 23 , at 376 . His comments would seem to be extremely prescient.

181. Concerns about the practicality of using a term as vague as "useful life" apparently dampened enthusiasm for the concept during formulation of the Interagency Report on Product Liability. See FINAL REPORT, supra note 6, at VII-26 to -28; see also Hodder v. Goodyear Tire \& Rubber Co., 426 N.W.2d 826, 830-31 (Minn. 1988) (expressing concerns about ambiguity of useful hife concept), cert. denied, 109 S. Ct. 3265 (1989).

182. "Period of repose" is the time in which a plaintiff may bring an action, regardless of whether that period is determined by the legislature or by the trier-of-fact.

183. See Hodder, 426 N.W.2d at 831.

184. See, e.g., ConN. GEN. STAT. § 52-577a(c)(1)-(5) (Supp. 1989); IDAHo CodE § 61403(1)(a) (Supp. 1989) KAN. STAT. ANN. § 60-3303(a)(1)(A)-(E) (1983); MiNN. STAT. § 604.03(2) (1988). 
definitional clarification. ${ }^{185}$ Those states enumerating specific factors have followed the lead of the Model Uniform Products Liability Act (MUPLA), with only minor exceptions. ${ }^{186}$ The MUPLA, therefore, serves as a convemient basis for analysis. The drafters of the MUPLA. suggested that the trier of fact examine five factors: (a) the wear and tear on the product; (b) deterioration of the product due to climatic conditions; (c) normal use and repair patterns; (d) manufacturer representations about use, care, and expected life; and (e) user modifications and alterations. ${ }^{187}$

These criteria suggest that the trier of fact examine the specific item involved in the accident, an approach this Note refers to as a productspecific test, rather than one that examines the manufacturer's productline generally. ${ }^{188}$ The Model Act's criteria (a), (b), and (e) all inquire into the specific conditions and treatment of the actual product in question, whereas (c) and (d) examine the treatment and expectations of users generally. The latter two factors appear to serve as an initial approximation of useful life which is to be modified by the more focused, productspecific mquiries.

With all due deference to the drafters of the MUPLA, an examination of the specific product involved in an accident may not be advisable. A reexamination of the strict hability system itself and of the motivating forces behind the adoption of useful life statutes reveals that a productspecific inquiry would destroy many of the original justifications for pursuing some measure of tort reform.

\section{A Proposal for Establishing Useful Life in Court}

Several factors argue against the use of a product-specific inquiry imto useful life. An examination of the particular product involved in an accident would necessarily require imtroduction of evidence concerning maintenance history, condition of the product at the time of mjury, particularly intensive or mild use, modifications or alterations, performance history and many other case-specific factors. The court undoubtedly will consider these factors in a determination of liability, but the question

185. See, eg., ARk. Stat. ANN. 16-116-105(c) (1987) (use beyond "anticipated life" is factor in comparative fault); TENN. CODE ANN. $\$ 29-28-102,103$ (1980) (action must be brought within 10 years from purchase or 1 year from expiration of "anticipated life," whichever is shorter); WASH. REv. CODE ANN. § 7.72.060(1)(a) (Supp. 1989) (manufacturer not liable after expiration of "useful sale life").

186. Minnesota, for example, includes progress of the art and developments in the industry to its list of faetors relevant to a product's useful life. See MinN. STAT. $\S 604.03(2)(2)(1988)$.

187. MUPLA, supra note $13, \S 110(\mathrm{~A})(1)(\mathrm{a})$-(e), 44 Fed. Reg. at $62,732$.

188. See Hodder, 426 N.W.2d at 831 (statutory criteria encompass variety of approaches to determining useful life). 
arises whether a fair result requires such an exhaustive examination of the product when determining the limitations period.

Useful life statutes were designed to introduce a degree of flexibility which was unavailable when using statutes of repose. A desire to individualize the determination of the limitations period, however, does not coinpel the conclusion that an in-depth analysis of each and every product, even within the saine product-line, is necessary to calculate the statutory useful life. Rather, the desire for flexibility requires ouly that the period of repose be determined in a less capricious fashion than the rigid legislative determination fostered by statutes of repose. Whereas the coinplete insensitivity to product variance in statutes of repose represents one end of the spectrum, a product-specific inquiry into useful life surely represents the other. Legislatures can reinain true to the goal of recognizing variance among products without venturing to this extreine. Moreover, an individualized examination of the product inay not be beneficial to plaintiffs. Although the use of a product-specific inquiry may lengthen the limitations by one or two years in soine instances, thereby allowing a plaintiff the opportunity to recover in a case in which he otherwise might have been barred, such an inquiry just as often will cut the other way. The evidentiary burdens imposed by this additional inquiry would not seein to justify the occasional benefit.

Furthermore, concentrating on the specific history of the product involved places the plaintiff at a decided advantage with respect to the inanufacturer. The plaintiff has control of the product in the interim period between inanufacture and injury and can introduce evidence deinonstratnig a history of above-standard perforinance, superior maintenance efforts, ideal operating conditions and minimal use or wear and tear. In contrast, the defendant has inadequate inforination regarding accidents, excessive use, or poor manitenance. Accordingly, the onesided information advantage the plaintiff enjoys suggests that case-specific evidence should not be introduced to show that this product had a longer than anticipated useful life. ${ }^{189}$

In addition, a broader examination of useful life is more likely to reflect the original expectations of the parties than a product-specific inquiry. At purchase, both parties rarely have in mind the precise use and conditions to which this particular product will be subjected over the

189. A defendant, however, would be given an opportunity to show that this particular product did not have the same useful life as similar products due to alteration, intense use, or poor maintenance. This evidence, however, would be admitted for liability but not limitations purposes. By allowing the defendant to use whatever evidence he does have available, the defendant would not be penalized for his lack of post-sale knowledge concerning the specific item, but still would be allowed to pursue this inquiry if she felt it would be advantageous. The plaintiff, of course, then would be allowed to rebut the contentions of the defendant. 
course of its lifetime. Rather, they typically will contemplate a general period during which the purchaser expects to enjoy reasonably safe use. The manufacturer has no knowledge of the purchaser's intentions with regard to imtensity of use or of the purchaser's stewardship qualities and, therefore, is incapable of estimating the expected period of liability for a particular product.

Although the point can be obscured, one must bear in mind that useful life statutes are designed not only to limit manufacturers' exposure to liability but to decrease actuarial uncertainties. Unless the legislature creates a clear standard for determining useful life, insurers and businesses will be unable to anticipate or forecast the extent of their liability. ${ }^{190}$ The need for certainty reinforces the suggestion that useful life be determined on a product-line, rather than product-specific, basis. Manufacturers and insurers familiar with an industry should be able to predict with reasonable certaimty the average length of time their products are intended or expected to last. In contrast, if legislatures adopt a productspecific inquiry, then insurers will have little lope of predicting the extent of the insured's liability. 191 As a result, useful life provisions will promote their intended goal of facilitating both planning and rate-setting while limiting the need for insurers to impose precautionary risk premiums only if based on a product-line inquiry.

For instance, if an accident occurred involving a 1984 Chrysler LeBaron, then, under a product-line test, both sides would introduce evidence regarding the average life of 1984 model LeBarons. This evidence should be fairly objective and easily calculable. In contrast, if a jury must determine useful life on the basis of a particular LeBaron by assigning a value to regular oil changes and an overhaul of the carburetor, discounting this by the effect of an earlier accident, and finally accounting for relatively intensive use over a short period of time, then the inquiry into useful life can become rather complex and ultimately arbitrary. Some might suggest that the jury's traditional function encompasses precisely this type of determination and that this situation presents no furtlier burdens. But when calculating a product's useful life, the jury is not engaged in its traditional function of deterinining liability. Instead, it is attempting to determine the period of limitation in a manner that is not only equitable but also predictable. In fact, it was precisely

190. See InSURANCE StUdy, supra note 71, at 4-91 (although useful life provides flexible, equitable approach, it also creates uncertainties that undermine goal of predictability of exposure); Note, supra note 19, at 517 (useful life concept so uncertain that cannot possibly add certainty to insurance rate-making).

191. In fact, it was precisely this concern over the uncertainty created by judicial determinations of useful life that animated many of the objections to the proposal during the Interagency study. See INSURANCE STUDY, supra note 71, at 4-91. 
this concern about the unpredictability of useful life statutes that caused the drafters of the MUPLA to adopt an intermediary approach establishing a ten-year presumptive period of useful life. If the useful life of a product cannot be predicted with certainty before the product's sale, then manufacturers will be unable to plan their affairs, msurers will continue to factor in risk premiums to cover the uncertainty of future hability, and the purpose for enacting measures of tort reform will be undermined. ${ }^{192}$

A inore pronounced delineation between the inquiry into hability and the apphicable period of limitation also should preserve scarce judicial resources. In a case raising the possibility of a useful life defense, the court can adopt a bifurcated approach to the trial in which the imitial proceeding only exammes evidence regarding average anticipated life. If the defendant successfully demonstrates to either the judge or jury that the average useful life of the product has expired, then the case can be dismissed without a time-consuming examination of the product in question. If the defendant fails to prove that the product's useful life has expired, then the trial will carry on as if the plaintiff had survived a motion to dismiss based on failure to comply with the applicable statute of limitation.

The use of a product-line, rather than product-specific, inquiry greatly simplifies the factors the trier of fact should consider when calculating the limitations period. Although the manufacturer's representations regarding anticipated hife should be considered, ${ }^{193}$ the producer should not be entitled to pre-set its own period of liability. ${ }^{194}$ The trier of fact also should consider the experience of other users and objective data concerning durability. ${ }^{195}$ Combined with the manufacturer's representations, these figures should yield a just and reasonably ascertainable estimate of the product's typical useful life.

The trier of fact also might calculate the limitations period based on an industry average of useful life. Certain conceptions about product quality, however, undoubtedly are built imto the original purchase price and, correspondingly, the consumer's expectations about durability. 196 One can imagine, for example, that a Mercedes would be designed to give

192. See supra note 99 and accompanying text (measures which limit manufacturer liability reduce uncertainty involved in rate-making).

193. The Model Act, as noted, does not include the manufacturer's representations in its criteria for determining useful life. See MUPLA, supra note 13, §110(A)(1)(d), 44 Fed. Reg. at 62,732; see also TENN. CODE ANN. § 29-28-102 (1980).

194. Cf. Henningsen v. Bloomfield Motors, Inc., 32 N.J. 358, 404, 161 A.2d 69, 95 (1960) (concluding that manufacturer's limited period of warranty could not limit liability).

195. See MUPLA, supra note $13, \S 110(\mathrm{~A})(1)(\mathrm{c}), 44$ Fed. Reg. at $62,732$.

196. See Schwartz, supra note 19 , at $838 \&$ n.252. 
effective service for a greater length of time than a Yugo, and at least some portion of the sale price would include this durability component. Useful life should be calculated based on the average life for a given manufacturer's product rather than an industry average to avoid the inequity of purchasing a high quality item with an extended hife only to have the period of hability watered down by averaging in the expected useful hives of inferior products.

In practice, a product-line determination of useful life more clearly delineates between the jury's determination of liability and its determination of the limitations period as einbodied in the concept of useful life. Under statutes that take product-specific factors into account, these two issues are interrelated, and the jury uses the same evidence to determine both liability and useful life. Under the product-line approach advocated in this Note, lowever, the defendant can only find relief under the statute by demonstrating that the injury occurred after the product-line's expected useful life has expired. Of course, the defendant can still pursue a non-statutory defense related to the specific product involved in the accident based on sucl factors as the use and repair patterns of that product. For example, although car manufacturers probably could not use a statutory useful life defense in an action involving a 1987 model car, they still Inay attempt to show that the vehicle has been driven over 150,000 miles in a three-year span and the part that failed was not defective but sinply wore out. Although such a claim imphicates useful life concerns, it would not be statutorily based since the intensity of use for this particular product is not part of the proposed statutory useful hife calculation. Conversely, the defendant would have a statutory defense against the owner of a 1955 model Ford, even if the car had been driven only 3000 miles. Thus, for the variety of reasons outlined above, the fundamental purpose of tort reform - to place an ascertainable limit on the extended liability of manufacturers-is severly hampered by the introduction of product-specific evidence.

Perliaps the most puzzhing aspect of the product-specific approach adopted by the MUPLA and the several states that liave followed its lead is that it adds so little to the traditional common law action. The adoption of criteria designed to determine the useful life of the specific product essentially returns the useful life concept to its common law origins. Strict liability cases outside the statutory context already focus exclusively on the product involved, the use to which it was subjected, repair patterns, modifications or alterations, and natural deterioration. Although the useful life approach was mitially conceived as a more flexible method of determining the period of limitation, the introduction of product-specific factors has merged the issue of liability with that of limi- 
tations, creating a singular approach which adds hittle to either the coininon law action or the tort reform effort. Although the statutory version of useful life does focus the jury's attention on the age of the product and turns the issue of product age into a limitations rather than habihty question, the two issues would be more clearly delineated if based on a product-line approach. Accordingly, a determination of useful life based on a reasonable approxiination of anticipated life for the product line will go further toward accomplishing the goals of tort reform while inaintaining the desired level of flexibility.

\section{E. Useful Life Statutes and the Incentive to Decrease Product Durability}

Some may suggest that defining the limitations period in relation to useful life will create incentives for inanufacturers to produce goods with abbreviated useful hives, thereby restricting their exposure to hability. Several factors question whether inanufacturers actually would attempt to reduce a product's anticipated life. First, for existing product lines, inanufacturers would expose themselves to a great deal of potential liability by creating a product that has a decreased useful life while the expectations of consuiners and objective data continue to reflect a longer product hife. For instance, if Chevrolet attempts to decrease the useful life of its Novas from eight to six years, it would take a full six model years before consumer expectations and the experience of other users coinpletely reflected the change in durability. Moreover, any attempt by inanufacturers to demonstrate that they inade a conscious decision to reduce the life of the product likely would receive a less than warm reception from a jury.

Second if manufacturers did shorten product hife to restrict the period of potential liability, they probably would not experience a decrease in the actual number of suits filed. Assuming manufacturers accoinphish a reduction in durability by using inferior component parts and inaterials, latent defects that einerged in the old product version prior to the expiration of the product's useful life will still occur before expiration of the new product's useful life. In other words, the saine defects will occur proportionately at the saine point in the products life-for example, after eighty percent of the product's anticipated life has expired (4.8 years for the new, but not inproved, Nova and 6.4 years for the old version). But both products would still be within their respective useful lives and thus subject to liability. For a reduction in the useful life to be effective, the latent defects tliat einerged in the old product soinehow must be con- 
strained from moving back in time with the expected life. ${ }^{197}$ Considering that manufacturers probably will use inferior materials to accomplish the decrease in durability, a reduction in hability is not likely. As a result, manufacturers would experience few if any benefits froin an attempt to restrict the period of liability by creating a less durable product.

The one possible drawback of useful life statutes is that they may retard any incentive to increase the product's useful life. If the industry involved is reasonably competitive, however, then market pressures to increase durability are likely to offset any countervailing incentive to reduce useful life. How the decisional calculus will play out in reality depends largely on the particular industry and whether or not competitive gains from an extended useful life counteract the expected increase in liability.

\section{F. Useful Life and Reasonable Notice of Liability Discontinuation}

In Hodder v. Goodyear Tire \& Rubber Co., the court concluded that before liability can be discontinued, the user must be aware that the product was beyond its useful life. 198 Without such a qualification, the court reasoned, the plaintiff would be left without a cause of action against the manufacturer through no fault of lis own. Although this view may seem equitable, it certaiuly misperceives the real issues presented to the court. Useful life statutes rest not on tlie subjective mindset of the individual and his knowledge of the product's age or useful life, but on the itein itself and whether or not a product of this kind should provide safe, effective service at this point in its life.

Although useful hife statutes are designed to temper the rigidity of statutes of repose, at heart they remain instruments of tort reform, designed to delimit the period of liability for manufacturers. By focusing on the individual knowledge of the user, the Hodder court's decision reads an enormous exception into the statute and undercuts the beneficial impact a useful life statute may liave in liniting liability.

The Hodder court, lowever, was not alone in its concern for user awareness of the expiration of the product's useful life. The Interagency Task Force proposed that a "warning" be placed on the product indicating the date of manufacture and the manufacturer's estimated life for the product. ${ }^{199}$ The report itself, however, recognized that bystanders in-

197. Cf. Epstein, The Temporal Dimension in Tort Law, 53 U. CHI. L. REv. 1175, 1214 (1986) ("It is very difficult to design a product which does harm only after the expiration of the statutory period ....").

198. 426 N.W.2d 826, 831 (Minn. 1988), cert. denied, 109 S. Ct. 3265 (1989).

199. See Final Report, supra note 6, at VII-27. 
jured by a product would not be aided by such a warning, ${ }^{200}$ nor would users be benefited if the warnings fell off, were obscured by wear, or were removed. If those injured by aging products must be aware that the product's useful life has expired before the statutory bar can take effect, then the rule itself will be emasculated. Useful life statutes would be irrelevant for all but the most egregious cases involving products that are patently unsafe. Yet inanufacturers would have won these cases even in the absence of a useful life statute. Moreover, courts have never required user awareness before statutes of repose can be enforced. Statutes of repose and useful life statutes are both limitations provisions which begin at manufacture and continue to run without regard to the user's state of mind. By limiting inanufacturers' hability, these statutes inay inpose costs on consuiners, but courts should not avoid this effect by circumventing the legislature's purpose.

One might argue that user knowledge of the expiration of the product's useful life should be required before the statute can bar a claim because, unlike with statutes of repose, the user has no advance notice that liability has been discontinued. In fact, the plaintiff has no way of knowing whether the injury occurred within the period of limitation until after the issue has been adjudicated. Although statutes of repose ostensibly provide greater notice to users by estabhishing a pre-set period of limitation, in reahty the distinction is less persuasive. Most users probably are unaware of the limitation on liability imposed by statutes of repose, considering few lay people spend time acquainting themselves with state legislation on such inatters. In fact, individuals are more likely to be acquainted with the generally expected useful life of a product.

The potential for useful life statutes to modify user behavior is also inuch greater than for statutes of repose. Users are unlikely to exercise a greater degree of caution with a product which is well within its anticipated life simply because the statute of repose is about to expire. In contrast, users inay devote more attention to product maintenance as the product approaches the expiration of its useful hfe, or they may actually discard a product that poses unreasonable risks of injury. In other words, useful hife statutes provide an intuitive conclusion to the period of liability. As a result, they actually may result in greater constructive notice than statutes of repose, which also may increase the behavior modification capabilities of the statute. Realistically then, statutes of repose do not offer any more notice to consumers than do useful life provisions.

200. Id. 
In an effort to provide notice to consumers, legislatures in useful life jurisdictions could require that inanufacturers place a warning on a product that includes the date of manufacture and its anticipated useful life. Even without such legislative enactments, plaintiffs may contend that the manufacturer failed to warn the purchaser of the product's useful life. To require a warning without an express legislative requirement, however, would oblige manufacturers to inform purchasers of their legal rights and the applicable limitations period. No such requirement exists under statutes of repose, and no such duty should be imposed under useful life statutes. Jurisdictions passing useful life statutes essentially put their populace on notice that extreme care should be exercised when using older products because traditional legal remedies may no longer be available.

\section{G. The Res Judicata Implications of an Initial Determination of Useful Life on Subsequent Claims Against the Same or Similar Product-Line}

Legislatures that have adopted useful life statutes have failed to consider whether the determination of useful hife by one jury will have a binding effect on subsequent actions involving the same or similar products. The doctrine of res judicata is designed to avoid needless litigation over issues that have already been resolved against a particular party. ${ }^{201}$ Although a res judicata claim usually must be asserted agamst a party to the previous hitigation, the asserting party need not have been involved in the prior judgment. ${ }^{202}$

The resolution of this issue in the useful life context turns mainly on the method courts use to determine useful life. If a court uses a productspecific analysis, then the issue in controversy, the product's useful life, will necessarily be different in each case. Thus plaintiffs in subsequent actions against the saine manufacturer could not assert a res judicata claim. However, if a court determines useful life based on the average expected life of the defendant's product hine, then, under traditional res

201. See Brown v. Felsen, 442 U.S. 127, 132 (1979) (res judicata ensures finality of decisions); Southern Pac. R.R. v. United States, 168 U.S. 1, 48-49 (1897) (once an issue has been put into question, hitigated, and decided the issue cannot be disputed in subsequent actions involving the same parties or their privies).

202. See United States v. Mendoza, 464 U.S. 154, 158-59 (1984) (offensive collateral estoppel allows non-party to use previous judgment against prior defendant); Southern Pac. Communications Co. v. AT\&T Co., 740 F.2d 1011, 1014 n.2 (D.C. Cir. 1984) (citing Parklane Hosiery Co. v. Shore, 439 U.S. 322, 326 n.4 (1979)) (defensive collateral estoppel allows non-party defendant to prevent relitigation of issue plaintiff lost in previous suit against another defendant); Bernhard v. Bank of Am. Nat'1 Trust \& Sav. Ass'n, 19 Cal. 2d 807, 813, 122 P.2d 892, 894 (1942) (Traynor, J.) (party against whom res judicata is asserted must have been party or in privity with party to prior action, but party asserting the claim need not). 
judicata principles, the initial jury determination will bind the defendant in subsequent actions.

Finally, if the court looks to an industry average for guidance, then the res judicata iniplications becone extremely unclear. Some courts have held that a defendant in the subsequent litigation is bound by the imitial determination of an issue if the first defendant was a predecessor in interest or in soine way provided virtual representation for the second defendant. ${ }^{203}$ In other words, if the court finds that the defendant's interests substantially comcided with those of the initial party litigating the same issue, then the disposition of the issue in the first action will be binding in the subsequent case.

Whether one manufacturer provided "virtual representation" for an unrelated inanufacturer of a similar product is a difficult issue. Because of the range of possible res judicata effects, legislatures passing useful life statutes should enunciate clearly the metlodology used in determining useful life and clarify what the corresponding collateral estoppel implications will be. ${ }^{204}$

\section{H. Concluding Thoughts}

Like a penduluin returning to equilibrium after venturing to extremes, useful life provisions can be used to strike an equitable balance between the virtually unlimited hability spawned by the combination of the discovery rule and strict liability, and the arbitrary limitations on liability created by statutes of repose. Although the face of products hability has changed with the ebb and flow of competing concerns over the course of the last forty years, the system has an opportunity to settle on a principle that achieves an appropriate balance between the various interests at stake.

203. See, e.g., Klugh v. United States, 818 F.2d 294, 300 (4th Cir. 1987) ("a non-party to an action may be bound by a judgment under res judicata if one of the parties to the action is so closely aligned with the interests of the non-party as to be his virtual representative"); Colby v. J.C. Penney Co., 811 F.2d 1119, 1125 (7th Cir. 1987) (virtual representation prevents relitigation of issue if interests of non-party and party in first suit were substantially aligned to provide adequate representation of interests); Cauefield v. Fidehity \& Casualty Co., 378 F.2d 876, 879 (5th Cir.), cert. denied, 389 U.S. 1009 (1967); In re Air Crash Disaster, Dayton, Ohio, on March 9, 1967, 350 F. Supp. 757, 767 (S.D. Ohio 1972) (when party's position is competently represented in prior action, issue will not be relitigated), rev'd sub nom. Humphreys v. Tann, 487 F.2d 666 (6th Cir. 1973), cert. denied, 416 U.S. 956 (1974).

204. Even if the courts determine that collateral estoppel would not apply in subsequent litigation involving different parties, the legislature may wish to provide for this result statutorily to avoid relitigation of what is essentially the saine issue. The legislature, however, may encounter a due process challenge. See, e.g., Blonder-Tongne Laboratories, Inc. v. University of Ill. Found., 402 U.S. $313,329-30$ (1971) (due process protects litigants who never appeared in prior action froin collateral estoppel even if identical issue already decided against them). 


\section{USEFUL LIFE AND THE DUTY TO WARN}

Any examination of useful life statutes would be incomplete without also addressing plaintiffs' efforts to evade the limitations provisions. In an effort to circumvent both useful life statutes and statutes of repose, plaintiffs have attempted to take advantage of a historical peculiarity associated with the duty to warn doctrine. The duty to warn places a continumg obligation on manufacturers to notify purchasers of either defects or hazardous uses associated with their products. ${ }^{205}$ In the pre-discovery rule era, courts interpreting statutes of limitation used the continuing duty theory to evade the traditional limitations language by liolding that the failure to fulfill this duty constituted a "contmuing course of conduct" that did not trigger the limitations period until the conduct at issue was complete. ${ }^{206}$ Plaintiffs in repose jurisdictions have argued, therefore, that failure to warn claims should not be susceptible to repose provisions that begin at manufacture, but instead, by incorporating the continuing course of conduct doctrine, to a limitations period that begins on injury.

The primary question in jurisdictions passing some forn of tort reform is whetlier the repose period for failure to warn claims begins to run at manufacture, or whether the nature of tlie breach creates an exception that does not trigger the limitations period until injury. If the continuing course of conduct exception is adopted, then statutes of repose and useful life statutes can be frustrated in cases in which the plaintiff can allege a breach of this duty.

\section{A. The Post-Sale and Point-of-Sale Duty to Warn}

The duty to warn lias two distinct forns, the point-of-sale duty and the post-sal duty. ${ }^{207}$ The point-of-sale duty requires manufacturers to warn consumers not of defects, but ratler of dangers associated with a

205. See, e.g., MUPLA, supra note $13, \S 104(\mathrm{C})(0), 44$ Fed. Reg. at 62,721 (providing for postmanufacture duty to warn).

206. See, e.g., Drakatos v. R.B. Denison, Inc., 493 F. Supp. 942,945 n.3 (D. Conn. 1980) (while Connecticut statute of limitation runs from date of negligence rather than injury, failure to warn is a contmuous duty that does not end until action is taken or an injury occurs); Boains v. Lasar Mfg. Co., 330 F. Supp. 1134, 1136 (D. Conn. 1971) (duty to warn is continuing course of conduct that does not end until injury); Berkenstem v. Potter \& Carrier Inc., 191 Conn. 150, 161, 464 A.2d 15, 24 (1983) (continuing course of conduct prevents statute of limitation from beginning until course of conduct is completed); Hodder v. Goodyear Tire \& Rubber Co., 426 N.W. 2d 826, 833 (Minn. 1988) (finding manufacturer had continuing post-sale duty to warn), cert. denied, $109 \mathrm{~S}$. Ct. 3265 (1989).

207. See, e.g., MUPLA, supra note 13, § 104(C)(1)-(6), 44 Fed. Reg, at 62,721 ((C)(1)-(5) pointof-sale duty and (C)(6) post-sale duty); see also Schwartz, The Post-Sale Duty to Warn: Two Unfortunate Forks in the Road to a Reasonable Doctrine, 58 N.Y.U. L. REV. 892, 893 (1983). 
particular use of the product. ${ }^{208}$ Armed with such knowledge, consumers presumably can adopt appropriate precautions. Under the Restatement of Torts, manufacturers must warn consumers of any danger associated with the product's use of which the consuiner ordinarily would be unaware. ${ }^{209}$ In this situation, the failure to warn is itself the defect at issue and the plaintiff need not maintain that the product was defectively inanufactured. ${ }^{210}$ Presumably, the defendant was aware of the danger associated with the product's use at manufacture, but simply neglected to take appropriate measures to warn the consumer. ${ }^{211}$

The post-sale duty to warn is limited to situations in which a defect in the product or a danger associated with its use comes to hight only after the original sale. ${ }^{212}$ The rationale for imposing a post-sale duty to warn is that manufacturers are usually in the best position to gather imformation concerning the performance problems associated with their products and disseminate this information to purchasers. ${ }^{213}$ Manufacturers serve as an informational hub, contacting original purchasers through the use of their sales records. The consensus among courts and commentators seems to be that the manufacturers must take reasonable measures to warn users of a subsequent defect or dangerous use. ${ }^{214}$ In fact, manufacturers of durable goods appear to assume that they have a

208. See MUPLA, supra note $13, \S 104(C)(1), 44$ Fed. Reg. at 62,721 (manufacturer liable for failure to warn of danger connected with product); RESTATEMENT (SECOND) OF TORTS § 402A comment (1965); see also Traynor, supra note 23 , at 372.

209. RESTATEMENT (SECOND) OF TORTS $\S 388(\mathrm{~b})$ comment $k$ (1965) (seller must warn of dangerous condition but only if she has no reason to expect users will realize danger).

210. Id. $\S 402 \mathrm{~A}$ comment $\mathrm{h}$ (product sold without adequate warning is defective).

211. A recent line of cases holds that the manufacturer does not need to have had knowledge of the danger before strict liability is imposed for failure to warn. See, e.g., Beshada v. Johns-Manville Prod. Corp., 90 N.J. 191, 205, 447 A.2d 539, 547 (1982) (refusing to recognize a state of the art defense which virtually destroys the knowledge requirement in duty to warn cases). Professor Victor Schwartz has argued that such a result is incongruous with the traditional failure to warn action because manufacturers cannot spread costs of liability for actions they cannot anticipate. Schwartz, supra note 207, at 903-04. Imposing a point-of-sale duty to warn without requiring knowledge also eliminates any incentive to discover and warn of a subsequently discovered dangerous use, since manufacturers will be held responsible for a violation of the point-of-sale duty regardless of their post-sale efforts. Id. at 897.

212. See, e.g., MUPLA, supra note 13, $\S 104(\mathrm{C})(6), 44$ Fed. Reg. at 62,721 (post-sale duty to warn apphies to "a danger connected with the product after it was manufactured").

213. See Dworkin, supra note 44, at 48-53; Epstem, Commentary, 58 N.Y.U. L. REv. 930, 931 (1983) (consumers report difficulties to manufacturers who are in best position to disseminate information to all consumers); $c f$. Schwartz, supra note 207, at 893 (knowledge about product's dangerous tendencies increases over time creating post-sale duty on manufacturer).

214. See MUPLA, supra note 13, § 104(C)(6), 44 Fed. Reg. at 62,725 (manufacturer satisfies obligation by making reasonable efforts to inform users); see also Braniff Airways, Inc. v. CurtissWright Corp., 411 F.2d 451, 453 (2d Cir. 1969), (if post-sale defects come to light, then manufacturer must warn or remedy), cert. denied, 400 U.S. 829 (1970); doCanto v. Ametek, Inc., 367 Mass. 776, 784-85, 328 N.E.2d 873, 878 (1975) (when manufacturer learns of risk associated with his product, he has "a duty to take reasonable steps to warn at least the purchaser of the risk"); Com- 


\section{duty to warn users about dangers discovered after manufacture or sale. ${ }^{215}$}

stock v. General Motors Corp., 358 Mich. 163, 176, 99 N.W.2d 627, 634 (1959) (court finds that defendant knew of defect after manufacture and thus had duty to warn owners).

The duty, however, has not been imposed absolutely, and courts often will consider several factors in determining whether the manufacturer had a duty to warn of subsequently discovered defects. Courts generally agree, however, that once a manufacturer discovers a product has an unanticipated defect, she must make "reasonable" efforts to inform users of the product. See West v. Broderick \& Bascom Rope Co., 197 N.W.2d 202 (Iowa 1972) (nnanufacturer must einploy efforts reasonably calculated to reach current users); Schwartz, supra note 207, at 893 . In determing reasonableness, the court balances the gravity and likelihood of harm against the economic and practical problens of reaching current users. See id. at 896. As time passes, the practical difficulties associated with contacting users increase as the product changes hands, original sales records are lost, and original purchasers relocate. Id. Thus, the assumption that the inanufacturer serves as an efficient informational conduit may no longer be realistic in situations in which it is difficult to notify current users. In these situations, less effort is required to satisfy the reasonableness test than in situations where the current users are easily identifiable. See Epstein, supra note 213, at 931. The amount expended in the notification effort can be used as a simple proxy for measuring effort under the reasonableness inquiry. Id. (recommending that cost be considered in determining if a reasonable effort has been made).

Manufacturers typically do not have a duty to inform consumers of subsequent safety improvement. See doCanto, 367 Mass. at 779, 328 N.E.2d at 877 . In fact, requiring post-sale notification of improveinents actually inay deter the efforts of manufacturers to upgrade their products. See Schwartz, supra note 207, at 899 n.34. Moreover, while the parties did expect a reasonably safe product, the original sale did not contemplate a continuing duty to improve the product. Id. at 932 (consumers did not expect inproved safety measures would be made available for free and price did not refiect cost of these as yet unknown improvements). If the assumption of safety proves incorrect, however, then the expeetations of the purchaser should be adjusted by a manufacturer's warning.

The difficulty comes in differentiating between an improvenent in a nondefective product, and subsequent discovery of either a defect or a specific use of the product that presents possible hazards to the user. In Labelle v. McCauley Indust. Corp., 649 F.2d 46 (1st Cir. 1981), for example, the defendant manufactured an airplane propeller that was involved in an accident. Subsequent safety inspections revealed that the plane's sharp edges caused internal cracks in the blade threatening their continued integrity in flight. Id. at 48. Although the defendant did revise its service manual for all licensed repair companies, it did not notify purchasers of the problem. The defendant argued that it was being held liable simply because it improved its product and took affirmativc efforts to impleinent the improvement. Id. at 49. The court rejected this claim and concluded that the decision to round the edges of the propeller was not a design improvennent, but rather the correction of a recognized defect. Id. In addition, the court held that even though the licensed service agents should have followed the safety instructions to round the edges, the manufacturer owes a duty to the purchaser when defeets arise after initial sale, not to the service agents. Id.

One possible definition of an improvement is a development of which the manufacturer was either unaware or incapable of accomplishing at the time of sale; the product manufactured was not unreasonably dangerous at manufacture; and the purchaser was aware, either as a inatter of common knowledge or due to warnings from the manufacturer, that there were certain risks involved in the use of the product. The inprovement would renove one of the risks associated with use without suggesting that the original product was defective.

215. See Epstein, supra note 213, at 930-33. 


\section{B. The Continuing Course of Conduct Doctrine}

Statutes of limitation typically bar actions brought more than a specified number of years after "the act or omission complamed of."216 Prior to the adoption of the discovery rule, courts generally held that manufacture was the "act complained of" in a products hability case.217 As a result, the limitations period would begin at manufacture, and plaintiffs could have their action barred even before injury, as often occurs under statutes of repose. ${ }^{218}$ In order to avoid the harsh effects on those injured by capital goods, plaintiffs have asserted that manufacturers have a continuing duty to warn consumers of known hazards associated with the use of their product. The failure to warn, therefore, would be the "omission complained of," an omission that continues until the date of injury. As a result, a plaintiff would have three years from the date of injury rather than from manufacture in which to bring an action.

The Connecticut Supreme Court in Handler v. Remington Arms Co. stated that "[w]hen the wrong sued upon consists of a continuing course of conduct, the statute does not begin to run until that course of conduct is completed."219 In other words, failure to warn claims involve a continuing duty which the defendant repeatedly breaches over time and which creates an exception to the normal functioning of the statute of limitation.

Some courts have atteinpted to limit the apphication of the continuing course of conduct doctrine by restricting its use only to cases in which a plaintiff asserts a claim based on the failure to warn of a dangerous use, rather than failure to warn of a defect. In Prokolkin v. General Motors Corp., for exainple, the Comrecticut Supreme Court nndertook an in-depth analysis of the interaction between duty to warn claims and Colmecticut's existing statute of limitation.220 Connecticut's limitation provision barred clains brought more than two years after injury and, in no event, more than three years after "the act or omission complained of," which the court concluded in the products hability context was the tinne of manufacture or sale. ${ }^{221}$ The court acknowledged that its construction of the statutory language would result in clains being barred

216. See supra notes 80-87 and accoinpanying text.

217. See supra notes 83-84 and accompanying text.

218. See, e.g., Prokolkin v. General Motors Corp., 170 Conn. 289, 296, 365 A.2d 1180, 1184 (1976).

219. 144 Conn. 316, 321, 130 A.2d 793, 795 (1975).

220. 170 Conn. 289, 365 A.2d 1180 (1976).

221. Id. at $294-97 \&$ n.5, 365 A.2d at $1182-84 \&$ n.5. 
before the plaintiff had even been injured.222 In this case, the plaintiff was injured more than three years after the original sale.223

As a result of the Connecticut Supreme Court's holding, the plaintiff attempted to follow an earlier line of cases that recognized the continuing course of conduct exception. He asserted that the defendant had learned of a defect in the brakes of its 1959 model Corvette after manufacture, but failed to notify purchasers of the danger. ${ }^{224}$ The plaintiff argued that the failure to warn constituted a continuing course of conduct, a repeated breach of the manufacturer's duty, which continued until the time of injury. ${ }^{225} \mathrm{Had}$ the defendant warned purchasers of the brakes' defective condition, the plaintiff inaintained that the injury might never have occurred. He argued, therefore, that the statute of limitation should not begin to run until mjury.

The court distinguished its earlier cases adopting the continuing course of conduct exception by noting that those cases involved negligent failure to warn causes of action, whereas the plaintiff in this case brought an action in strict hability. ${ }^{226}$ The court found that in a strict liability failure to warn action, the failure to warn is not "the act or omission complained of," rather the underlying defect lies at the heart of the action. ${ }^{227}$ In contrast, the court held that in an action for neghigent failure to warn, the "wrong sued upon" is the failure to warn itself. Thus the plaintiff in this situation is not contending that the product itself is defective, but rather that the defendant knew of potential hazards associated with the product's use and neglected to warn consumers. The court concluded that the failure to warn clain in a strict hability action is superfluous; it merely uses different terminology to complain of the same actthe original defect. If the court had dismissed the failure to warn claim, then the plaintiff still would have the underlying action for defective manufacture. ${ }^{228}$ To allow the plaintiff to base a failure to warn claim on the underlymg defect would permit the plaintiff to circumvent the statute of limitation and assert substantially the same clain under a different naine. Conversely, im neghigent failure to warn cases, a dismissal of the claim would leave the plaintiff without a remedy, since the only defect complained of would be the lack of a warning itself. Accordingly, the Prokolkin court found it reasonable to treat these two causes of action

222. Id. at 296,365 A.2d at 1184 .

223. $I d$.

224. Id.

225. Id.

226. Id. at $299,365 \mathrm{~A} .2 \mathrm{~d}$ at 1185 .

227. Id.

228. Id. 
differently for limitations purposes and to bar failure to warn claims premised on an underlyimg defect. ${ }^{229}$

Prokolkin was decided prior to the adoption of the discovery rule, and as a result, the court's analysis is directly applicable to useful life jurisdictions in which the limitations provisions also begin at manufacture. The court provides one example of how failure to warn clamis and the continumg course of conduct exception may be treated in jurisdictions adopting useful life statutes which, like pre-discovery rule statutes of limitation, begin the limitations period manufacture. Yet there are several possibilities regarding the appropriate interaction between sucli claims and useful life statutes.

\section{The Continuing Course of Conduct Doctrine in Useful Life Jurisdictions}

1. Failure to Warn Claims Not Based on Product Defects. The Prokolkin court concluded that a negligent failure to warn claim apphed only to the failure to warn of a dangerous use-in otler words, a failure to warn that was itself the defect-whereas an action in strict liability represented failure to warn of an underlying defect. ${ }^{230}$ Today, however, courts view neghigent and strict liability failure to warn actions as virtually indistimguishable. ${ }^{231}$ Although the labels themselves may no longer be appropriate, the court's distinction between failure to warn of an underlying defect and failure to warn of a dangerous use remains relevant to the discussion of useful life statutes. Transposed into the useful life context, the Prokolkin court's distinction might permit the continuing course of conduct exception to validate clains based on the failure to warn of a hazardous use even after the expiration of the product's useful life. ${ }^{232}$ Sucli claims are not premised on events relatimg to manufacture and a plaintiff might argue that they should not be barred by a useful life statute beginning at that time.

229. Id.

230. Id. at 297-98, $365 \mathrm{~A} .2 \mathrm{~d}$ at 1184.

231. See, e.g., Higgirs v. E.I. DuPont de Numours \& Co., 671 F. Supp. 1055, 1060 (D. Md. 1987) (interpreting Md. law) ("[I]n failure to warn cases, whether asserted on negligence or strict liability grounds, there is but one unitary theory of liability which is negligence based-the duty to use reasonable care in promulgating a warning"); see also Epstein, supra note 197, at 1214 \& n.87 (1986) (difficult to find principled difference between negligence and strict liability theories in modern failure to warn cases).

232. In Hodder v. Goodyear Tire \& Rubber Co., 426 N.W.2d 826 (Minn. 1988), cert. denied, 109 S. Ct. 3265 (1989), discussed infra at notes 251-66 and accompanying text, the court found that a failure to warn claim can be asserted despite the fact the product's useful life had expired. The court, however, did not draw a distinction between negligent and strict liability failure to warn claims. 
At one level, the analysis is rather straightforward: Claims based on a defendant's failure to notify purchasers of a subsequently discovered defect are tied to the time of manufacture due to their reliance on the product defect and therefore such claims should not be allowed to avoid the useful life limitations provisions. Yet the analysis actually runs much deeper. If the useful life determination is construed to establish a point at which natural deterioration, rather than product defect, is responsible for the accident, then the distinction between the two failure to warn actions becomes particularly important. The assumption that wear-andtear is responsible for the injury simply does not apply in the failure to warn context when a plaintiff asserts a claim premised on the failure to warn of a dangerous use. Such claims do not implicate the condition of the product, and the expiration of the product's useful life should not present a bar to the plaintiff's recovery. In this situation, the failure to warn of a dangerous use and the useful life statute are like two ships passing in the night, they simply do not interact. On the other hand, failure to warn claims premised on an underlying defect would understandably be barred by the expiration of the useful life because the assertions about a defect relate to the condition of the product.

This interpretation, however, rests on the assuniption that useful life statutes establish the poimt at which any subsequent nialfunction is presumed to be the consequence of deterioration ratlier than defect. If instead useful life is viewed as a case-by-case method for determining the period of repose, a position this Note ultimately adopts, then such a distinction will have no effect on the functioning of the statute and all claims, nicluding failure to warn of dangerous use claims, will be barred by its provisions.

Althougl the Prokolkin court's delineation between the failure to warn of subsequently discovered defects and the failure to warn of a dangerous use may serve as one model for determining how repose provisions and failure to warn claims might interact, there are several other ways in which the two theories legitiniately may be linked.

2. All Failure to Warn Claims Are Created Equal. Another possibility is to enibrace completely the continuing course of conduct exception and find that all failure to warn claims are capable of circuniventing various repose provisions. The Prokolkin court stated that the plaintiff was asserting a failure to warn of the original defect, and thus the defect, not the failure to warn, was the act or omission about which the plaintiff complained. The court concluded, therefore, that the statute of linnitations should begin at manufacture, and the contimuing course of conduct exception should not be available. 
There are several problems with this interpretation. First, the plaintiff in Prokolkin asserted two distimct claims: (1) the product was defectively manufactured, and thus the inanufacturer was strictly liable for the injuries that resulted; and (2) after inanufacture, the defendant learned of the defect but failed to notify Corvette purchasers. Each claim has its own eleinents and requirements which are separate and distinct froin the other.

For example, a manufacturer can be held strictly hable for a defective product regardless of whether or not he was aware of the defect and took all possible ineasures to avoid it. ${ }^{233}$ Before hability can be imposed in a failure to warn claim, however, a plaintiff inust demonstrate that the defendant had knowledge of the dangerous use or defect but neglected to alert consumers. ${ }^{234}$ The original defect, although indispensable to the plaintiff's failure to warn claim, is not the gravamen of a failure to warn complaint. The "omission complained of" is the failure to fulfill the duty to warn, and the statute of limitations should begin on the last day the defendant breached this duty - the date of injury. Under this analysis, all failure to warn clains are separate and distinct causes of action which are properly perceived as creating a continuing obligation regardless of whether the failure to warn refers to a defect or a dangerous use. In this hight, the distmction made by the court in Prokolkin is an umecessary and unconvincing limitation on the continuing course of conduct doctrine.

In addition, whether the failure to warn is itself the defect or the plaintiff claims a failure to warn of a defect, an appropriate warning at any time in the product's life inay alert the consuiner to a possible danger and prevent an accident from occurring. Accordingly, courts inay allow such claims to avoid useful life provisions because a warning inay have prevented the injury despite expiration of the product's useful life. In Alabaina, for instance, the legislature has recoginzed the contimuing prophylactic capabilities of warnings and has adopted the continuing course of conduct exception for all duty to warn cases. The Alabama statute

233. See Restatement (SECOND) OF TORTS § 402A(2)(a) (1965).

234. See Lohrmann v. Pittsburgh Corning Corp., 782 F.2d 1156, 1165 (4th Cir. 1986) (manufacturer should be judged based on knowledge at time of manufacture); Feldman v. Lederle Laboratories, 97 N.J. 451-53, 479 A.2d 276, 386-87 (1984) (state of the art defense applicable in non-asbestos cases). But see Kisor v. Johns-Manville Corp., 783 F.2d 1337, 1342 (9th Cir. 1986) (interpreting Wash. law) (reversible error to admit evidence of the manufacturer's knowledge in strict liability case); Petree v. Victor Fluid Power, Inc., 831 F.2d 1191, 1194 (3rd Cir. 1987) (liability imposed for failure to warn despite lack of knowledge of defects); Beshada v. Johns-Manville Prods. Corp., 90 N.J. 191, 204-05, 447 A.2d 539, 546-47 (1982); Phillips v. Kimwood Mach. Co., 269 Or. 485, 491501, 525 P.2d 1033, 1038-40 (1974). 
creates a specific exemption from its ten-year statute of repose if a government agency has required the manufacturer to issue a warning. ${ }^{235}$

3. The Post-Sale, Point-of-Sale Dichotomy in Repose Jurisdictions. The problem can be approached from another perspective. Statutes of repose or useful life provisions can be interpreted as focusing on the time of breach, which historically has been at the time of manufacture in the products hability arena. Accordingly, courts examining failure to warn claims in the context of a useful life statute may draw a distinction between point-of-sale and post-sale duties to warn. Point-of-sale duties are breached when the manufacturer sells a product without warning consumers of possible dangerous uses. Since the point-of-sale duty is breached at sale, it logically should be subject to the provisions of the useful life statute or statute of repose that begins running at the time of manufacture or sale. ${ }^{236}$ The post-sale duty, in contrast, results from a subsequent discovery of a hazardous use or defect and would not be subject to a limitations period that begins at inanufacture. 237 Unlike the conclusions of the Prokolkin court, which tied failure to warn of a defect to manufacture for limitations purposes, this analysis recognizes that the duty to warn of a defect only arises in the post-sale context. Failure to warn of an underlying defect creates a separate and distinct cause of action which should be treated as a continuing breach until the duty to warn is met. ${ }^{238}$ As a result, the assertion of a post-sale duty to warn would allow the plaintiff to evade the statutory provisions of a useful life statute. ${ }^{239}$

The author acknowledges that the case law does not recognize a distinction between point-of-sale warnings and post-sale warnings in applying the contimuing course of conduct exception. The exception, however, was developed under the old limitations language of "the act or omission complained of," and it was not designed with repose provisions in mind. ${ }^{240}$ The emergence of a new limitations period necessitates a

235. AlA. Stat. ANN. $\S 6-5-502$ (e) (1989) (creating an exception to 10-year bar when the government orders recall, inspection, or repair).

236. See supra note 208-12 and accompanying text.

237. See supra notes $212-15$ and accompanying text.

238. See supra notes 220-29 and accompanying text (suggesting that failure to warn of an underlying defect is distinct from action for defective product).

239. Courts rejecting such a reading claim that it would virtually eviscerate the effect of a repose provision, see infra notes $245-50$, as almost any claim can be framed in failure to warn language. Usually the manufactuer will have some indication that the product has problems that serve as the basis for a claim the manufacturer had knowledge of a defect or dangerous use, but neglected to take action warning consumers.

240. Moreover, if point-of-sale and post-sale duties are not held to a differing standard for repose purposes, there is limited incentive for the manufacturer who discovers a subsequent defect or hazardous use to attempt to alert purchasers, considering that only a limited period of liability remains. 
reappraisal of the interaction between the continuing course of conduct exception and the limitations language. If useful life statutes are interpreted as initiating the limitations period at the point the defendant breaches his duty, then courts may wish to associate point-of-sale duties and post-sale duties with differing starting points for limitations purposes. ${ }^{241}$

\section{The Inconsistency Between Repose Provisions and the Continuing} Course of Conduct Exception. A reexamination of the original justifications for imposing the notion of a "continuing course of conduct" reveals a great deal about the appropriate interplay between statutorry repose provisions and failure to warn claims. The continuing course of conduct exception antedates the discovery rule doctrine and is designed to ameliorate the harsh impact of statutes of limitation that, by starting on manufacture, functioned much like today's statutes of repose. ${ }^{242}$ Whereas the discovery rule bluntly states that the limitations period should not begin until the plaintiff discovers the injury, ${ }^{243}$ the continuing course of conduct exception adheres more closely to the traditional limitations language. The doctrine states that the failure to warn is "the omission coinplained of," and the continuing omission results in a himitations period that begins at injury rather than at inanufacture.

Although the continuing course of conduct exception inay have been an appropriate judicial substitute for the discovery rule in jurisdictions retaining traditional limitations fornulations, it is simply inconsistent with both useful life statutes and statutes of repose. Repose provisions represent a legislative rejection of the discovery rule or any interpretation of the limitations language that begins on injury. These provisions substitute a limitations process initiated not by mjury, but rather by manufacture or sale of the product.

Just as the discovery rule no longer applies in jurisdictions adopting statutes of repose or useful life statutes, neither should the continuing

For example, if the manufacturer of a product with a useful life of ten years (or if the manufacturer is subject to a ten-year statute to repose) discovers a defect or dangerous use in year nine, it will have little incentive to undertake the costs of warning customers and instead may attempt to gamble on escaping through the remaining repose period without suffering liability. The recognition of the continuing course of conduct exception for post-sale failure to warn, therefore, provides an extended period of liability and added incentive for producers to undertake a notification effort.

241. Due to the evidentiary difficulties involved in proving the precise point in time at which the defendant had sufficient knowledge to constitute a breach, the point-of-sale/post-sale distinction would have the odd effect of encouraging defendants to claim they had knowledge at the point-ofsale, so that the repose period would start from that point.

242. See supra notes $83-91$ and accompanying text.

243. The continuing course of conduct exception also might be viewed as redundant in light of the discovery rule's overarching role in the products liability field. 
course of conduct exception enjoy continued vitality. The continuing course of conduct exception developed in another era, in connection with different statutory limitations language, and for the limited purpose of allowing injured individuals nore time in which to bring an action. Since the adoption of the discovery rule, the continuing course of conduct doctrine has becoine redundant. Useful life statutes and statutes of repose are a legislative negation of the discovery rule, passed in an effort to prohibit precisely the type of ongoing, extended hability which the continuing course of conduct exception perpetuates. These statutes were designed to provide insurers with greater certainty in predicting potential hability and inanufacturers with greater certainty in planning their affairs. As one commentator has stated in analyzing whether negligence actions should be covered by the apphicable statute of repose: "The point of [statutes of repose] is to ban actions that should not be brought; it is not to encourage deft pleading by skilled plaintiffs lawyers deternnined to make an end run around the ban." 244 In short, repose provisions are desigued to strictly delimit the period of liability to which inanufacturers are exposed. Allowing the continuing course of conduct doctrine to enjoy continued apphication would severely vitiate the intended effect of such legislation.

The MUPLA and several state codes support this conclusion, and specifically provide that the language of their repose provisions is intended to cover all actions brought against product inanufacturers, including failure to warn claims. For example, the MUPLA covers claims in strict hability, neghigence, warranty, and failure to warn. ${ }^{245}$ The Washington state code provides that the inanufacturer "shall not be subject to liability to a claimant under this chapter" if by a preponderance of the evidence the defendant shows that the useful safe life has expired.246 And Washington courts have concluded that the duty to warn is covered by the chapter, and such claims are barred after the product's useful life expires. ${ }^{247}$ Courts in Tennessee and Indiana also have interpreted their statutes as barring negligent failure to warn clains brought after the expiration of the repose period. ${ }^{248}$ Likewise, Connecticut's products liability statute has been construed as providing the exclusive remedy for

244. See Epstein, supra note 197, at 1214.

245. See MUPLA, supra note 13, § 102(D), 44 Fed. Reg. at 62,719; McGovern, supra note 3, at $582 \mathrm{n} .9$ (expiration of useful life should bar further duty to warn).

246. WASH. REV. CODE ANN. $\$ 7.72 .060$ (1989).

247. See Morse v. City of Toppenish, 46 Wash. App. 60, 64-65, 729 P.2d 638, 641 (1986).

248. See Wilson v. Dake Corp., 497 F. Supp. 1339 (E.D. Tenn. 1980) (rejecting plaintiffs effort to avoid 10 year bar under Tennessee statute of repose by claiming a continuing duty to warn); Dague v. Piper Aircraft Corp., 275 Ind. 520, 418 N.E.2d 207, 212 (1981) (although failure to warn is continuing duty and defendant's actions resulted in continuing breach, 10-year statute of repose meant defendant only liable for breach occurring during that period). 
plaintiffs injured by manufactured goods. ${ }^{249}$ The language of the statute indicates that the product liability act "sliall be in lieu of all other claims against product sellers."250

5. Hodder v. Goodyear Tire \& Rubber Co. In Hodder v. Goodyear Tire \& Rubber Co., ${ }^{251}$ the Minnesota Supreme Court ruled on precisely these issues, exarnining the interplay between useful life statutes and the failure to warn doctrine. In contrast to the position taken in this Note, the Hodder court held that the plaintiff's failure to warn claim could successfully avoid the useful life statute involved.

In 1978, the Minnesota legislature passed a useful life statute governing product hability claims in an effort to limit the indefinite hability to which inanufacturers were exposed.252 The Act provides that expiration of the product's ordinary useful life constitutes a defense against product liability claims directed at manufacturers. ${ }^{253}$

The plaintiff in Hodder was changing a customer's tire when the Goodyear rim assembly unit "explosively separated," resulting in serious injury. ${ }^{254}$ The rim involved was inanufactured in 1955, almost twentysix years before the date of injury. The plaintiff asserted that the product was designed defectively and that defendant Goodyear and its distributor failed to warn users of the product's dangerous propensities when improperly maintained.

The jury, however, concluded that the useful life of the rim assembly unit had expired, and that the product was not defectively inanufactured in 1955.255 Yet despite these two findings, the jury held the defendant hable for its failure to warn users of the product's dangerous propensities. As a result, the jury imposed compensatory damages of nearly $\$ 3.4$ Inillion, and punitive dannages of $\$ 12.5$ million..$^{256}$

On appeal, the plaintiff argued that the useful life defense was simply one factor to be considered in the jury's determination of liability,

249. Arsenault v. Pa-Ted Spring Co., 203 Conn. 156, 157, 523 A.2d 1283, 1284 (1987) (product liability act provides exclusive remedy and plaintiff cannot use common law right of action for negligent failure to warn to defeat repose); Daily v. New Britain Mach. Co., 200 Conn. 562, 569, 512 A.2d 893, 899 (1986) (act meant to provide exclusive remedy to plaintiff, therefore all products liability actions subject to its limitations).

250. ConN. GEN. STAT. $§ 52-572$ n(a) (1989) (emphasis added).

251. 426 N.W.2d 826 (Minn. 1988).

252. Id. at 830 .

253. MiNN. STAT. $\S 604.03(1)$ (1988). The statutory language states that "In any action ... arising out of the manufacture, sale, use or consumption of a product, it is a defense . ... that the injury was sustained following the expiration of the ordinary useful life of the product." Id.

254. Hodder, 426 N.W.2d at 829.

255. Id.

256. Id. 
whereas the defendant contended that once the jury determines that the useful life of the product has expired, then the statute creates an absolute bar to recovery. ${ }^{257}$ The court recognized that useful life statutes are simply one variation on statutes of repose in which the trier of fact determines the limitations period, rather than the legislature. ${ }^{258}$ Curiously, the court was unwilling to conclude that the jury's finding that the useful life of the product had expired should be treated in the same fashion as a legislative mandate. Rather, the court agreed with the plaimtiff, concluding that the useful life of the product was only one factor to be considered in the jury's deliberations. ${ }^{259}$

The jury in this case had concluded that the product as manufactured was not defective and that Goodyear did not have sufficient knowledge of potential dangers at inanufacture to warn purchasers. As a result, the jury imposed a post-sale duty to warn users not of a subsequent defect, but of dangers associated with the product's use. The Minnesota Supreme Court summarily concluded that Goodyear had a contmuing duty to warn consumers of potential dangers as they came to light, even after the expiration of the product's useful life. ${ }^{260}$ Presumably, the court found that the continuing nature of the duty prevented Minnesota's useful hife statute from functioning as an absolute bar to recovery.

The court, however, neglected to discuss the basis on which this determination rested. The jury and court may have concluded that if adequate warnings had been made, then the plaintiff might not have been injured, thereby justifying the defendant's liability even after the product's useful life had expired. Alternatively, the court may have decided that the plaintiff's complaint alleged a failure to warn which was itself the defect and therefore the statute's assumptions about the role played by wear and tear simply were inapplicable, thereby exempting the claim froin an otherwise valid useful life defense. Or perhaps the court determined that the defendant breached a post-sale duty and should not be shielded by a statute which starts its limitations period at inanufacture. Any of these theories, although criticized in this Note, would have provided a reasonable justification for imposing liability after expiration of a product's useful life. The court, however, did not reveal the theory upon which it based its rather surprising conclusion.

Both the goal and common understanding of useful life statutes recognize a need to provide relief from liabihty of all kinds after the expira-

257. Id. at 830 .

258. Id.

259. Id. at 832 .

260. Id. at 833 . 
tion of a product's useful life. Although the legislature legitimately might have been concerned about providing incentives for inanufacturers to warn consumers of dangers or defects even after the expiration of the product's useful life, it did not so provide. With this in mind, the court should have required that the statute specifically exempt failure to warn claims from the useful life defense, rather than insist that the statute specifically include such claims. Any doubt should have been resolved in favor of accomplishing the underlymg goals of the statute. For useful hife statutes to be effective, the manufacturer's duty to users must cease upon the expiration of the useful hife, regardless of whether the duty was breached within the product's lifetime or not.

Apparently, the Hodder court used the contimuing course of conduct exception to hold that the duty to warn was breached within the useful life and continued to the time of injury, rendering product age irrelevant. Yet the court appropriately notes that if it is to have any effect at all, the statute should cover defects present at inanufacture that he undiscovered until after the expiration of the typical product's useful life. ${ }^{261}$ Similarly, breaches of the duty to warn may occur within the product's useful life, but if injury does not result until after the useful life expires, then the action should be barred. Although useful life statutes are based im part on assunptions about the effects of product deterioration, an individual would be denied recovery even if he could demonstrate that the accident was a result of an actual defect rather than wear and tear, and the court acknowledges as much. Therefore, despite the fact that failure to warn claims which are premised on a dangerous use do not implicate the condition of the product, they should still be barred by an applicable useful life statute. Simply stated, the court ignored the fact that it was interpreting a variable or flexible statute of limitation, not a codified version of existing common law liability principles. Under the court's analysis, Minnesota's treatinent of claims against older products is no different after passage of the useful life statute than it was prior to passage.

The decision is even more disturbing, however, when one recognizes that virtually any product hability claim can be dressed up as a failure to warn action. Unless the accident is undeniably the first of its kind, the plaintiff can introduce evidence of past accidents to demonstrate that the

261. Id. at 831 (stating that if useful life statutes do not cover originally defective products, then they will be irrelevant for most product liability cases). 
defendant had knowledge of a problem but failed to take ameliorative action. 262

The court relies on articles questioning the practicability of the useful life concept, ${ }^{263}$ seemingly without understanding that the application of the statute was not in question, only the effect. The jury overcame the obstacles to determining the period of useful life and concluded that the product's useful life had expired. The only remaming question was what legal effect this finding should liave. It seeins clear that when the trier of fact concludes the product's useful life has expired, then the defendant no longer owes the plaintiff the traditional product liability duties. ${ }^{264}$ Courts may disagree with this result, but the intent of sucli statutes is to limit open-ended liability for aging products, ${ }^{265}$ an intent which is undoubtedly frustrated by the holding in this case.

\section{CONCLUSION}

Useful life statutes initially were suggested as a method of avoiding the liarsh impact statutes of repose had on innocent plaintiffs. By allowing the trier of fact greater flexibility to determine the period of limitation, useful life statutes establisli a far less arbitrary limitation on hability. Yet, despite their praiseworthy motivations, useful life statutes still represent an effort to limit the extended hability of manufacturers, and as such will bar an action that otherwise miglit be viewed as meritorious. The concept, however, strikes an equitable balance between protecting the legal riglits and interests of putative plaintiffs, while protecting manufacturers from indefimite hability.

Uufortunately, several of the states that adopted useful life standards defined the concept in relation to the specific product involved in the accident. This approach bears a curious resemblance to a traditional cominon law action im which the defendant attempts to demonstrate that the product's failure resulted from natural deterioration rather than a defect. It merges the question of liability with the determination of the limitations period by incorporating many of the factors already considered in the absence of a statute. In essence then, state legislatures attempting to temper the rigidity of statutes of repose overshot the mark by adopting a product-specific approach to useful life. More importantly, a

262. See, e.g., Walsh v. National Seating Co., 411 F. Supp. 564, 570 (D. Mass. 1976) ("[A]lmost every products liability case has the potential issue of failure to warn."); Hodder, 426 N.W.2d at 834 (discussing introduction of past accidents to establish Goodyear was aware of problem).

263. Id. at 832.

264. See Final RePORT, supra note 6, at VII-28 (judge should instruct jury that manufacturer is not liable for imjuries occurring beyond ordinary useful life).

265. Hodder, 426 N.W.2d at 830 ("[T]his much is ccrtain: The legislature was concerned about expanding products liability and intended to limit open-ended liability for aging products."). 
product-specific determination fails to provide the ascertainable period of limitation which originally prompted products hability reform efforts.

By focusing the concentration of the trier of fact on the defendant's product-line generally, rather than the specific product involved in the accident, useful hife statutes can achieve equitable results while accomplishing the goals of tort reform. A generalized determination of useful hife comports with the expectations of the parties and allows the trier of fact the fiexibility needed to temper the harsh impact of statutes of repose. In addition, a product-line approach provides an added degree of certainty to the insurance underwriting process, not only by reducing the number of clains, but by defiming a predictable period over which liability should be anticipated. While statutes of repose inay add greater certainty, any incremental benefit is vastly outweighed by the severe inequities imposed on prospective plaintiffs.

Yet useful life statutes will be of httle practical value if they can be evaded simply through the skillful pleadings of ingenuitive practitioners. As a result, courts should reject claims based on the failure to warn or the continuing course of conduct exception. The continuing course of conduct exception developed in another era under markedly different statutory language and simply is no longer apphicable in the context of repose provisions. To give continued vitality to this doctrine results in precisely the type of ongoing hability useful life statutes sought to avoid.

Commentators and legislators have suggested and attempted numerous reforin efforts over the years, but few offer the combination of equity and efficiency achieved by useful life statutes. If properly calculated, they offer a flexible period of limitation that accommodates the interests of plaintiffs, defendants, and insurers. Perhaps the systein which began solely as an effort to compensate injured individuals lias ventured to an extreme and untenable position. If it has, then useful life statutes represent a reasonable first step toward remedying the imbalance.

Robert A. Van Kirk 